\title{
Endothelin receptors in renal interstitial cells do not contribute to the development of fibrosis during experimental kidney disease
}

\author{
Thomas H. Neder $^{1} \cdot$ Julia Schrankl ${ }^{1} \cdot$ Michaela A. A. Fuchs ${ }^{1} \cdot$ Katharina A. E. Broeker $^{1} \cdot$ Charlotte Wagner $^{1}$ (D)
}

Received: 18 March 2021 / Revised: 24 June 2021 / Accepted: 1 July 2021 / Published online: 6 August 2021

(C) The Author(s) 2021

\begin{abstract}
Renal interstitial fibrosis is characterized by the development of myofibroblasts, originating from resident renal and immigrating cells. Myofibroblast formation and extracellular matrix production during kidney damage are triggered by various factors. Among these, endothelins have been discussed as potential modulators of renal fibrosis. Utilizing mouse models of adenine nephropathy (AN) and unilateral ureter occlusion (UUO), this study aimed to investigate the contribution of endothelin signaling in stromal mesenchymal resident renal interstitial cells. We found in controls that adenine feeding and UUO caused marked upregulations of endothelin-1 (ET-1) gene expression in endothelial and in tubular cells and a strong upregulation of $\mathrm{ET}_{\mathrm{A}}$-receptor $\left(\mathrm{ET}_{\mathrm{A}}-\mathrm{R}\right)$ gene expression in interstitial and mesangial cells, while the gene expression of $\mathrm{ET}_{\mathrm{B}}$-receptor $\left(\mathrm{ET}_{\mathrm{B}}-\mathrm{R}\right)$ did not change. Conditional deletion of $\mathrm{ET}_{\mathrm{A}}-\mathrm{R}$ and $\mathrm{ET}_{\mathrm{B}}-\mathrm{R}$ gene expression in the FoxD1 stromal cell compartment which includes interstitial cells significantly reduced renal $\mathrm{ET}_{\mathrm{A}}-\mathrm{R}$ gene expression and moderately lowered renal $\mathrm{ET}_{\mathrm{B}}-\mathrm{R}$ gene expression. ET receptor (ET-R) deletion exerted no apparent effects on kidney development nor on kidney function. Adenine feeding and UUO led to similar increases in profibrotic and proinflammatory gene expression in control as well as in $\mathrm{ET}_{\mathrm{A}}{ }^{\mathrm{flfl}} \mathrm{ET}_{\mathrm{B}}{ }^{\mathrm{flfl}}$ FoxD $1^{\mathrm{Cre}+}$ mice (ET-Ko). In summary, our findings suggest that adenine feeding and UUO activate endothelin signaling in interstitial cells which is due to upregulated $\mathrm{ET}_{\mathrm{A}}-\mathrm{R}$ expression and enhanced renal ET-1 production Our data also suggest that the activation of endothelin signaling in interstitial cells has less impact for the development of experimentally induced fibrosis.
\end{abstract}

Keywords Endothelin-1 · Endothelin receptors · Kidney fibrosis $\cdot$ Unilateral ureter occlusion · Adenine-induced nephropathy

\section{Introduction}

Development and progression of renal fibrosis is a characteristic of chronic kidney disease and is widely believed as the consequence of an excess accumulation of extracellular matrix (ECM) proteins such as collagens, fibronectin, or tenascins [7, 27, 46, 55]. Progressive fibrosis results in deterioration of tubular and glomerular function [63]. It is well established that myofibroblasts are the key mediators of fibrosis by serving as the primary matrix/collagen-producing cells. These myofibroblasts transdifferentiate from several cell types including fibroblasts, pericytes, monocytes, tubular, and

Charlotte Wagner

charlotte.wagner@ur.de

1 Institute of Physiology, University of Regensburg, Universitätsstraße 31, D-93053 Regensburg, Germany endothelial $[6,15,18,20,28,31,41,64]$. There is broad agreement that fibroblasts, pericytes, and bone marrowderived cells contribute equally to the myofibroblast population $[6,15,32,37,39]$. Resident fibroblasts and pericytes derive from the FoxD1 ${ }^{+}$stroma progenitor cell population, and they express the platelet-derived growth factor receptor $\beta$ (PDGFR- $\beta$ ) [37]. A recent study showed that in human kidneys mainly PDGFR- $\beta$ cells undergo transformation into myofibroblasts [37].

Among a variety of cytokines and signaling factors involved in myofibroblast formation and the progression of fibrosis, the role of ET-1 has been studied in various experimental models $[2,5,45,48]$. ET-1 binds to either $\mathrm{ET}_{\mathrm{A}^{-}}$or $\mathrm{ET}_{\mathrm{B}}-\mathrm{R}$ which mainly activate the inositol triphosphate signaling cascade intracellularly $[26,50,52]$. In damaged kidneys, an increase of ET-1 and $\mathrm{ET}_{\mathrm{A}}-\mathrm{R}$ mRNA expression has been already reported [1, 9, 33, 43, 44, 65]. An important role of ET-1 in renal fibrosis was elucidated from the finding that transgenic mice overexpressing human ET-1 develop renal abnormalities associated with interstitial fibrosis [25] and that 
inhibitors of endothelin receptors can attenuate experimentally induced fibrosis [5, 45, 48]. Since ET-R are expressed in different cells of the kidney, it is difficult to gain insights into the cell type-specific roles of ET-R by experiments systematically inhibiting the ET-1 signaling pathway. This could explain some of the controversial reports in recent years $[2,5,35$, $45,48]$.

In view of the major role of interstitial cells as precursors of myofibroblasts, we were interested to define the role of endothelin signaling in this cell population.

To this aim, we generated a mouse model with constitutive genetic ablation of both $\mathrm{ET}_{\mathrm{A}^{-}}$and $\mathrm{ET}_{\mathrm{B}}-\mathrm{R}$ in cells descending from the stroma progenitor cell population which is characterized by the specific expression of the transcription factor FoxD1. Besides interstitial fibroblasts/pericytes, also vascular smooth muscle cells, renin-producing cells, and mesangial cells derive from the $\mathrm{FoxD}^{+}$progenitor cell population $[40$, 57]. ET-Ko mice were studied in two models of experimental renal fibrosis, unilateral ureter occlusion (UUO) and adenine-induced nephropathy ( $\mathrm{AN}$ ). AN is a chronic damage model mediated by precipitation of crystals within the tubular lumen leading to kidney injury similar to that in human crystal-induced pathologies $[6,32,51]$. UUO, on the other hand, represents an acute damage model for mechanical stress $[6,10]$. In these pathological models, the effects of ET-R deletion in stromal cells on the expression of $\alpha$-SMA as a marker for myofibroblast formation were examined. Furthermore, we investigated the profibrotic and proinflammatory gene expression.

\section{Material and methods}

\section{Animals}

$\mathrm{ET}_{\mathrm{A}}{ }^{\text {flfl }} \mathrm{ET}_{\mathrm{B}}{ }^{\text {flfl }}$ FoxD1 ${ }^{\mathrm{Cre}+}$ mice were generated by crossbreeding FoxD ${ }^{\mathrm{Cre}+}$ mice (JAX stock \#029684) and mice with loxP-flanked $\mathrm{ET}_{\mathrm{A}}$ (obtained from Dr. M. Yanagisawa at the Howard Hughes Institute at University of Texas Southwestern Medical Center) [30] and loxP-flanked $\mathrm{ET}_{\mathrm{B}}$ alleles (obtained from Dr. M. Epstein, University of Wisconsin, Madison) [14]. Genotyping was performed using the primers listed in Table 1.

Table 1 Primer sequences used for genotyping of mice.

\begin{tabular}{lll}
\hline Genotype & Sequence (5'to 3'), fwd & Sequence rev (5'to 3'), rev \\
\hline FoxD1 $^{\text {Cre }}$ & gaactgtcaccggcagga & aggcaaattttggtgtacgg \\
ET $_{\mathrm{B}} \mathrm{KO}$ & tggaatgtgtgcgaggcc & cagccagaaccacagagaccaccc \\
$\mathrm{ET}_{\mathrm{B}} \mathrm{wt}$ & ctgaggagagcctgattgtgccac & cgactccaagaagcaacagctcg \\
ET $_{\mathrm{A}}$ flox & gggtggcatttaccaccaga & gcgtagcctcacaagcacat \\
\hline
\end{tabular}

Littermates negative for Cre were used as control animals. Animals were maintained on standard rodent chow $(0.6 \%$ $\mathrm{NaCl}$; Ssniff, Soest, Germany) with free access to tap water. All animal experiments were performed according to the Guidelines for the Care and Use of Laboratory Animals published by the US National Institutes of Health and approved by the local ethics committee.

\section{Adenine-induced nephropathy}

Adenine-induced fibrosis was generated in adult mice for this study $[6,29,32,51]$. Male mice were fed with adenine containing diet $(0.2 \%)$ continually for 3 weeks. Experiments were performed after exactly 3 weeks (3-week adenine).

\section{Unilateral ureteral obstruction}

Under inhalation anesthesia, a ureteral ligation was placed close to the right kidney through a small abdominal incision [15]. Mice were kept under close observation after the operation for $72 \mathrm{~h}$. Five days after the procedure, mice were killed and perfused for RNAscope, or the kidneys were removed for mRNA quantification.

\section{In situ hybridization via RNAscope}

Localization of mRNA was studied with the RNAscope Multiplex Fluorescent v2 kit (Advanced Cell Diagnostics ACD, Hayward, CA, USA), according to the manufacturer's instructions. The kidneys were perfusion-fixed with $10 \%$ neutral buffered formalin solution, dehydrated in an ethanol series, and embedded in paraffin. Hybridization signals were detected on $5 \mu \mathrm{m}$ tissue sections using the TSA ${ }^{\circledR}$ Plus fluorophores Cy3 and Cy5 (PerkinElmer, Waltham, MA). Slices were mounted with ProLong Gold Antifade Mountant (Thermo Fisher Scientific, Waltham, MA) and viewed with an Axio Observer.Z1 Microscope (Zeiss, Jena, Germany). Positive and negative controls were routinely enclosed. RNAscope ${ }^{\circledR}$ probes are listed in Table 2.

\section{Determination of mRNA expression by real-time PCR}

Total RNA was isolated from kidneys as described by Chomczynski and Sacchi [11] and quantified by a photometer. Of the resulting RNA, $1 \mu \mathrm{g}$ was used for reverse transcription. cDNA was synthesized by Moloney murine leukemia virus RT (Thermo Fisher Scientific, Waltham, MA). For quantification of mRNA expression, real-time PCR was performed using a LightCycler Instrument and the LightCycler 480 SYBR Green I Master Kit (Roche Diagnostics, Mannheim, Germany). mRNA expression data were normalized to glyceraldehyde 3-phosphate dehydrogenase (GAPDH). 
Table 2 RNAscope probes used for in situ hybridization

\begin{tabular}{ll} 
RNAscope ${ }^{\circ}$ probe & Cat no. \\
\hline Mm-ET1 & 435221 \\
Mm-ETA & 486351 \\
Mm-ETB & 473801 \\
Mm-Pdgfrb-C2 & $411381-C 2$ \\
Mm-CD31-C2 & $316721-C 2$ \\
Mm-Col1a1 & 319371 \\
Mm-F4/80 & 460651 \\
Mm-asma & 319531 \\
2.5 Duplex Positive Control Probe-Mm & 321651 \\
2-plex Negative Control Probe & 320751 \\
\hline
\end{tabular}

Sequences of the primers for the real-Time PCR are shown in Table 3.

\section{Immunohistochemistry}

For immunoreactivity 5- $\mu$ m sections of the kidneys fixed in $3 \%$ PFA were blocked with $10 \%$ horse serum/1\% BSA in PBS and were incubated either with rabbit anti ET-1 (ab117757, Abcam, Cambridge, UK), mouse anti- $\alpha$ SMA (ab7817, Abcam, Cambridge, UK), or rabbit anti-colla1 (ab34710-100, Abcam) in different experimental approaches at $4^{\circ} \mathrm{C}$ overnight. After washing with BSA/PBS, sections were incubated with Cy3 and Cy5 secondary antibodies (Dianova, Hamburg, Germany), mounted with Glycergel (Agilent, Waldbronn, Germany), and viewed with an Axio Observer. Z1 Microscope.

Table 3 Primer sequences used for real time PCR

\begin{tabular}{|c|c|c|}
\hline Genes & Sequence $\left(5^{\prime}-3^{\prime}\right)$ & Sequence $\left(3^{\prime}-5^{\prime}\right)$ \\
\hline Colla1 & ctgacgcatggccaagaaga & atacctcgggtttccacgtc \\
\hline Col3al & ggtggttttcagttcagctatgg & ctggaaagaagtctgaggaatg \\
\hline ET1 & ccacagaccaggcagttagat & tgaatggtactttgggccctga \\
\hline ETA & aggaacggcagcttgcggat & agcaacagaggcaggactga \\
\hline ETB & ggagagcggtatgcagattg & tattgctggaccggaagttg \\
\hline Fibronectin & tccagccccaccetacaagt & ccagaccaaaccataagaac \\
\hline Tenascin $\mathrm{C}$ & tgaaccacaagaaataaccctc & gttgctatggcactgactgg \\
\hline CX3CR1 & aagttccettcceatctgct & caaaattctctagatccagttcagg \\
\hline CX3CL1 & cacctcggcatgacgaaat & ttgtccacccgettctcaa \\
\hline GAPDH & caccagggctgccatttgca & gctccacccttcaagtgg \\
\hline$\alpha-\mathrm{SMA}$ & actgggacgacatggaaaag & catctccagagtccagcaca \\
\hline
\end{tabular}

\section{Systolic blood pressure measurement}

Systolic blood pressure of conscious mice was determined by tail-cuff manometry (TSE Systems). Animals were placed into the holding device for 5 consecutive days before the first measurement. Blood pressure was measured daily for 10 days in a row, and the average of these measurements was used for analysis.

\section{Determination of glomerular filtration rate}

For glomerular filtration rate (GFR) measurement, FITC-labeled sinistrin (3.74 $\mu \mathrm{l} / \mathrm{g}$ body wt) was injected retro-orbitally in a single bolus. Approximately $5 \mu \mathrm{l}$ of blood was collected from the tail vein of conscious mice at 3, 7, 10, $15,35,55$, and $75 \mathrm{~min}$ after injection. After centrifugation, $0.5 \mu \mathrm{l}$ of the plasma samples were diluted in HEPES $(0.5 \mathrm{M}$, $\mathrm{pH}$ 7.4), and FITC fluorescence was measured by Invitrogen Qubit 3.0 Fluorometer (Thermo Fisher Scientific).

\section{Urine analysis}

Urine osmolality was determined by freezing point measurements of the urine samples (Osmomat 030, Gonotec). Urine sodium and potassium concentrations were determined by flame photometer (XP flame photometer; BWB Technologies).

The determination of ET-1 in urine was carried out with an ET-1 ELISA from R\&D Systems (Minneapolis, MN, USA) according to the manufacturer's instructions. Measurements of the urine albumin concentration were determined with an albumin ELISA (ICL, E-90AL, Portland, OR, USA) according to the manufacturer's instructions.

\section{Determination of hematocrit values, plasma renin, and plasma erythropoietin concentration}

Blood samples were taken from tail vein into EDTA-coated capillary tubes to prevent clotting. Hematocrit values were determined after centrifugation ( $8 \mathrm{~min}, 8,000 \mathrm{rpm})$. The erythropoietin (EPO) concentration was determined in plasma samples using the Quantikine Mouse EPO ELISA kit (R\&D Systems, Minneapolis, MN) according to the manufacturer's protocol. Plasma renin concentration was determined by measuring the capacity of plasma samples to generate ANG I in the presence of excess renin substrate. Therefore, plasma samples were incubated for $90 \mathrm{~min}$ at $37^{\circ} \mathrm{C}$ with plasma from bilaterally nephrectomized male rats. The generated ANGI (in $\mathrm{ng} \cdot \mathrm{ml}^{-1} \cdot \mathrm{h}^{-1}$ ) was determined by ELISA (IBL International, Hamburg) according to manufacturer's protocol. 


\section{Determination of plasma urea and creatinine concentrations}

Plasma urea concentration was determined in plasma samples using the QuantiChrom ${ }^{\mathrm{TM}}$ Urea Assay Kit ( Bioassay Systems, CA, USA) according to manufacturer's protocol. Plasma creatinine concentration was determined by Creatinine Serum Detection Kit (Arbor Assays, MI, USA) according to manufacturer's protocol.

\section{Statistical analyses}

All data are presented as mean \pm SEM. Statistical significance was determined by ANOVA. $p<0.05$ was considered statistically significant. The data were analyzed using GraphPad Prism8.

\section{Results}

\section{The endothelin system is activated during experimental kidney disease}

\section{Endothelin 1}

ET-1 mRNA expression was localized by RNAscope on kidney sections of healthy control mice. ET-1 mRNA was detected in endothelial cells of glomeruli and endothelial cells lining intrarenal blood vessels (Fig.1). ET-1 mRNA hybridization signals were the strongest in the cortical zone but more faint in the outer and inner medulla where they appear in the endothelium of capillary renal vessels (Fig 1). Adenine feeding for 3 weeks and unilateral ureter occlusion (UUO) for 5 days led to a 15 - and 8-fold increase in ET-1 mRNA abundance,
Fig. 1 Basal expression of ET-1 mRNA on kidney sections of control mice. Details showing RNAscope for ET-1 mRNA (red) in cortex (A), outer $(\mathbf{B})$, and inner medulla $(\mathbf{C})$ on a control kidney section. ET-1 mRNA was detected within glomeruli (glom) and renal vessels (arrows). Merged details of the co-hybridization of ET-1 with the endothelial marker CD31 (green) (D, E, F) revealed endothelial cells as the only expression site of ET-1 synthesis in the healthy kidney. Scale bars = $50 \mu \mathrm{m}$
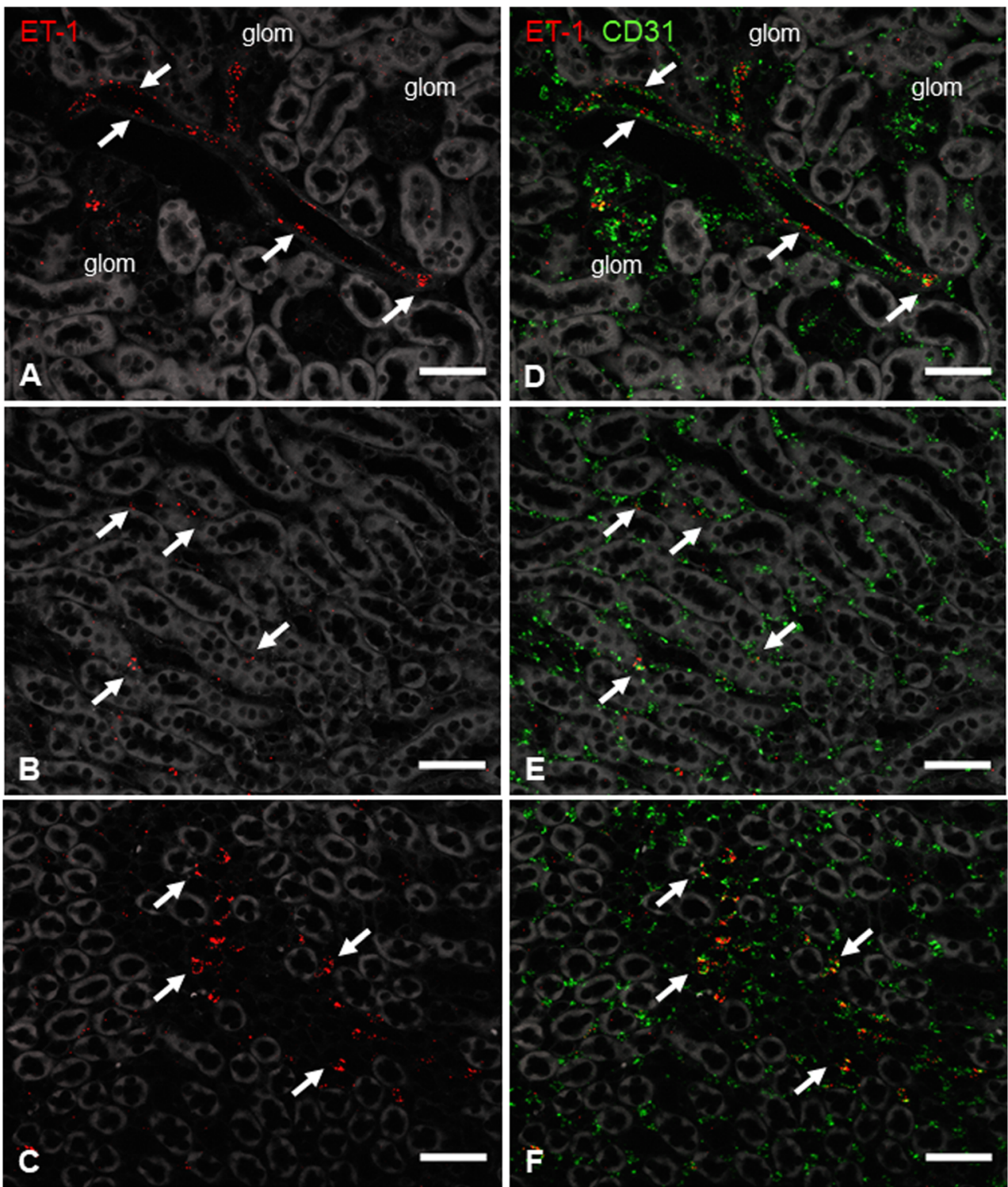
respectively (Fig. 2). Upregulated ET-1 expression was observed in endothelial cells and de novo in tubular cells (Fig. 3).

\section{ET receptors}

RNAscope for $\mathrm{ET}_{\mathrm{A}}$ mRNA showed clear hybridization signals in vascular smooth muscle cells, mesangial cells, and mesenchymal interstitial cells of the healthy kidney (Fig. 4). The latter two cell types could be identified by co-hybridization with PDGFR- $\beta$ (Fig. 4, upper panel) while $\mathrm{ET}_{\mathrm{A}}-\mathrm{R}$ expression in vascular muscle cells was confirmed by co-hybridization with $\alpha$-SMA (Fig.4, lower panel). All $\mathrm{ET}_{\mathrm{A}}-\mathrm{R}$ mRNA expressing cells have their origin in the FoxD1-positive stroma precursor compartment. During adenine feeding and UUO, $\mathrm{ET}_{\mathrm{A}}$ mRNA expression increased about 5-fold (Fig. 5A, B), whereas ET $_{\mathrm{B}}-\mathrm{R}$ mRNA remained unchanged (Fig. 5C).

Co-RNAscope for $\mathrm{ET}_{\mathrm{B}}-\mathrm{R}$ mRNA and the endothelial marker CD31 showed expression of $\mathrm{ET}_{\mathrm{B}} \mathrm{R}$ in glomerular, perivascular, and vascular endothelial cells (Fig. 6). In addition, $\mathrm{ET}_{\mathrm{B}}-\mathrm{R}$ mRNA was found in different tubular segments (Fig. 6) and also showed weak expression in the medial layer of renal vessels ( Fig. 6, lower panel).

Upregulation of $\mathrm{ET}_{\mathrm{A}}-\mathrm{R}$ mRNA in experimental kidney disease mainly occurred in renal interstitial cells which are substantiated by co-hybridization of $\mathrm{ET}_{\mathrm{A}}-\mathrm{R}$ and PDGFR- $\beta$ in renal interstitial fibroblasts that showed an enhanced expression of both genes (Fig. 7). During adenine treatment and $\mathrm{UUO}$, renal $\mathrm{ET}_{\mathrm{B}}-\mathrm{R} \mathrm{mRNA}$ abundance remained unaltered as already shown in Figure $5 \mathrm{C}$.

The upregulation of $\mathrm{ET}_{\mathrm{A}}-\mathrm{R}$ gene expression in the stromal compartment in conjunction with the enhanced endothelial and tubular expression of the ligand ET-1 during experimentally induced kidney fibrosis raised the question about the role of enhanced endothelin signaling in stromal cells for the development of interstitial fibrosis. Since, in addition to the dominant $\mathrm{ET}_{\mathrm{A}}-\mathrm{R}$ expression in the FoxD1 compartment, vascular smooth muscle cells show a weak abundance of $\mathrm{ET}_{\mathrm{B}}-\mathrm{R}$, we addressed this question by generating mice with deletions of both endothelin receptors in the stroma cell compartment $\left(\mathrm{ET}_{\mathrm{A}}{ }^{\text {flfl }} \mathrm{ET}_{\mathrm{B}}{ }^{\text {flfl }}\right.$ FoxD1 ${ }^{\mathrm{Cre}+}$ mice $)$.

\section{Renal function of $\mathrm{ET}_{A}{ }^{\text {flfl }} \mathrm{ET}_{B}{ }^{\text {flfl }} \mathrm{FoxD} 1^{\mathrm{Cre}+}$ mice is apparently normal}

Endothelin receptor knockout mice developed normally. They had no significant difference in body weight nor showed a different kidney to body weight ratio compared to control littermates (Table 4).

Gross renal histology revealed no apparent abnormality in ET-Ko mice. In line, renal functional parameters in ET-Ko mice were not changed compared to controls (Table 5). This suggests that deletion of both endothelin receptors in renal stromal progenitors and their descendants does not disturb normal kidney function.
Fig. 2 ET-1 mRNA abundance in control mice under basal and pathological conditions. A RNAscope for ET-1 mRNA expression on whole kidney sections of control mice under basal conditions, after adenine feeding for 3 weeks and UUO for 5 days. Scale bars $=500 \mu \mathrm{m}$. B ET- 1 mRNA abundance of control mice under basal condition, after adenine feeding and after UUO for 5 days. Renal ET-1 mRNA levels increased 15 -fold due to adenine nephropathy and 8-fold after UUO for 5 days. All data are means \pm SEM of at least 5-8 animals per condition. Single asterisk is $p<0.05$ compared to untreated animals
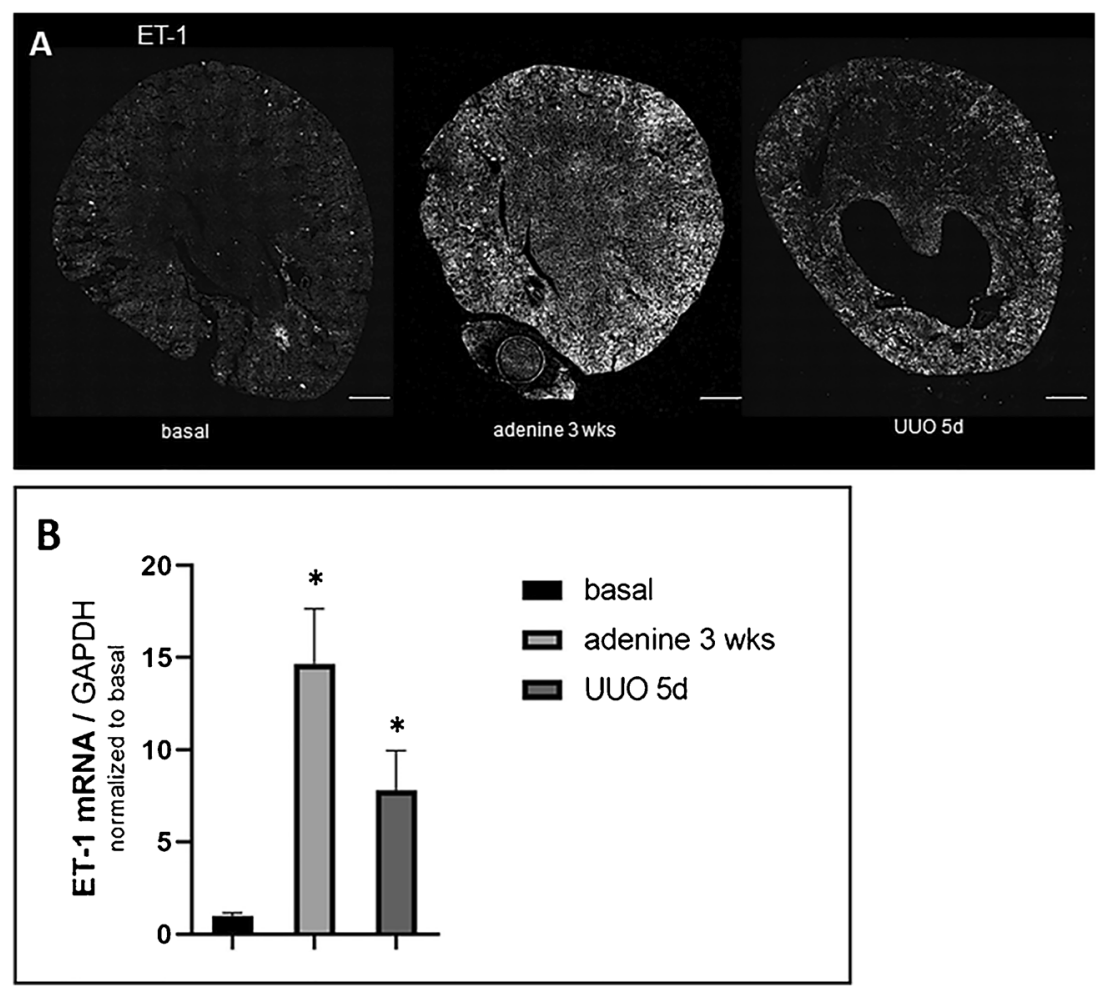
Fig. 3 ET-1 mRNA localization in the control kidney under basal and pathological conditions. ET-1 mRNA localization in the mouse kidney under basal conditions (upper panel), after 3 weeks of adenine feeding (middle panel) and 5-day UUO (lower panel). Asterisks indicate ET-1 expression (red) in tubular segments, the finely dotted line indicates ET-1 within renal vessels, the coarser dashed line surrounds glomeruli. Co-hybridization with the endothelial marker CD31 (green) revealed ET-1 production in endothelial cells of glomeruli, in the endothelium of renal vessels and peritubular capillaries. Scale bars $=50 \mu \mathrm{m}$
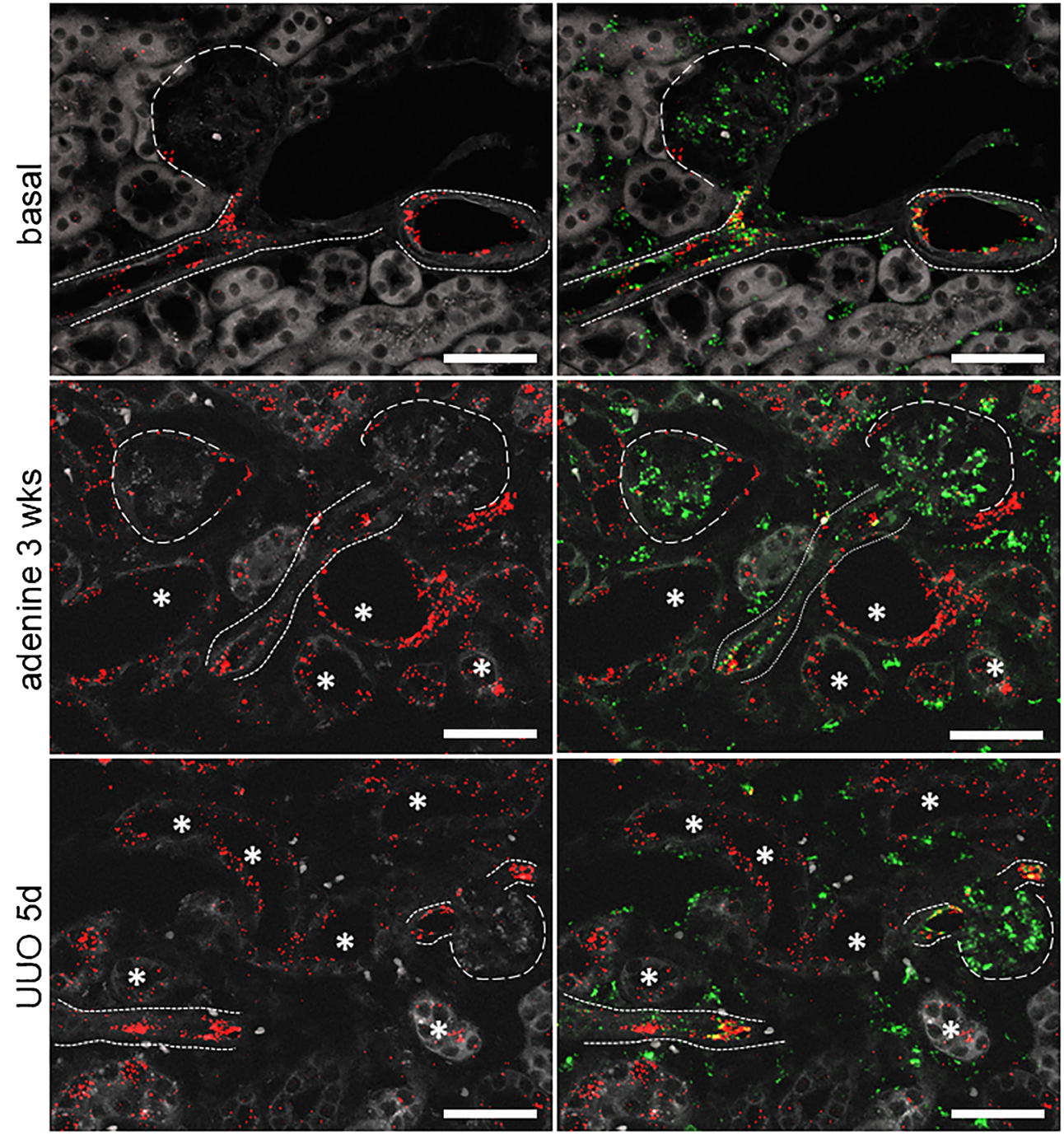

\section{Endothelin system in ET-Ko mice in health and disease}

In endothelin receptor knockout mice, renal endothelin-1 mRNA expression under basal conditions was similar to control animals. Accordingly, also adenine feeding and UUO led to similar increases of ET-1 mRNA expression in ET-Ko mice as observed in controls (Fig. 8). The comparison of the ET-1 protein expression in healthy and fibrotic kidneys of control and ET-Ko mice yielded a comparable result (Suppl-Fig.1).

Basal $\mathrm{ET}_{\mathrm{A}}$ mRNA expression in endothelin receptor knockout kidneys was significantly reduced by around $90 \%$ compared to the kidneys of control mice. (Fig. 9A). The marked increase in $\mathrm{ET}_{\mathrm{A}}$ mRNA observed in control kidneys during adenine feeding or UUO was also greatly attenuated in the ET-Ko kidneys (Fig. 9B), which suggests that the increase in $\mathrm{ET}_{\mathrm{A}}-\mathrm{R}$ gene expression during the experimental fibrosis probably took place mainly in the stromal FoxD1 compartment.
The basal $\mathrm{ET}_{\mathrm{B}}$ mRNA abundance was reduced by about $25 \%$ in the endothelin receptor knockout kidneys (Fig. 10A), indicating that $\mathrm{ET}_{\mathrm{B}}$ is mainly expressed outside the FoxD1 compartment with the exception of its expression in vascular smooth muscle cells. This could explain the moderate decrease in its expression in the knockout model. Adenine treatment and UUO did not change the $\mathrm{ET}_{\mathrm{B}}-\mathrm{R}$ mRNA expression in control and endothelin receptor knockout kidneys (Fig. 10B).

\section{Disruption of the ET signaling in stromal cells does not influence myofibroblast development in experimental kidney disease}

Development of fibrosis is typically characterized by the formation of myofibroblasts that express $\alpha$-SMA. In the healthy kidney, expression of $\alpha$-SMA mRNA was mainly seen in the medial layer of renal vessels (Fig. 11A). Adenine treatment 
Fig. 4 Details of an RNAscope for $\mathrm{ET}_{\mathrm{A}} \mathrm{mRNA}$ localization on kidney sections of control mice. RNAscope for $\mathrm{ET}_{\mathrm{A}}$ (red) with cohybridization of the mesenchyma cell marker PDGFR- $\beta$ (green) in the upper panel showed ETA in mesangial cells within glomeruli (dotted line) and in renal interstitial cells (arrowheads). $\mathrm{ET}_{\mathrm{A}}$ mRNA is also synthesized in vascular smooth muscle cells of renal vessels (arrows), clarified by a-SMA co-localization. Scale bars $=50 \mu \mathrm{m}$
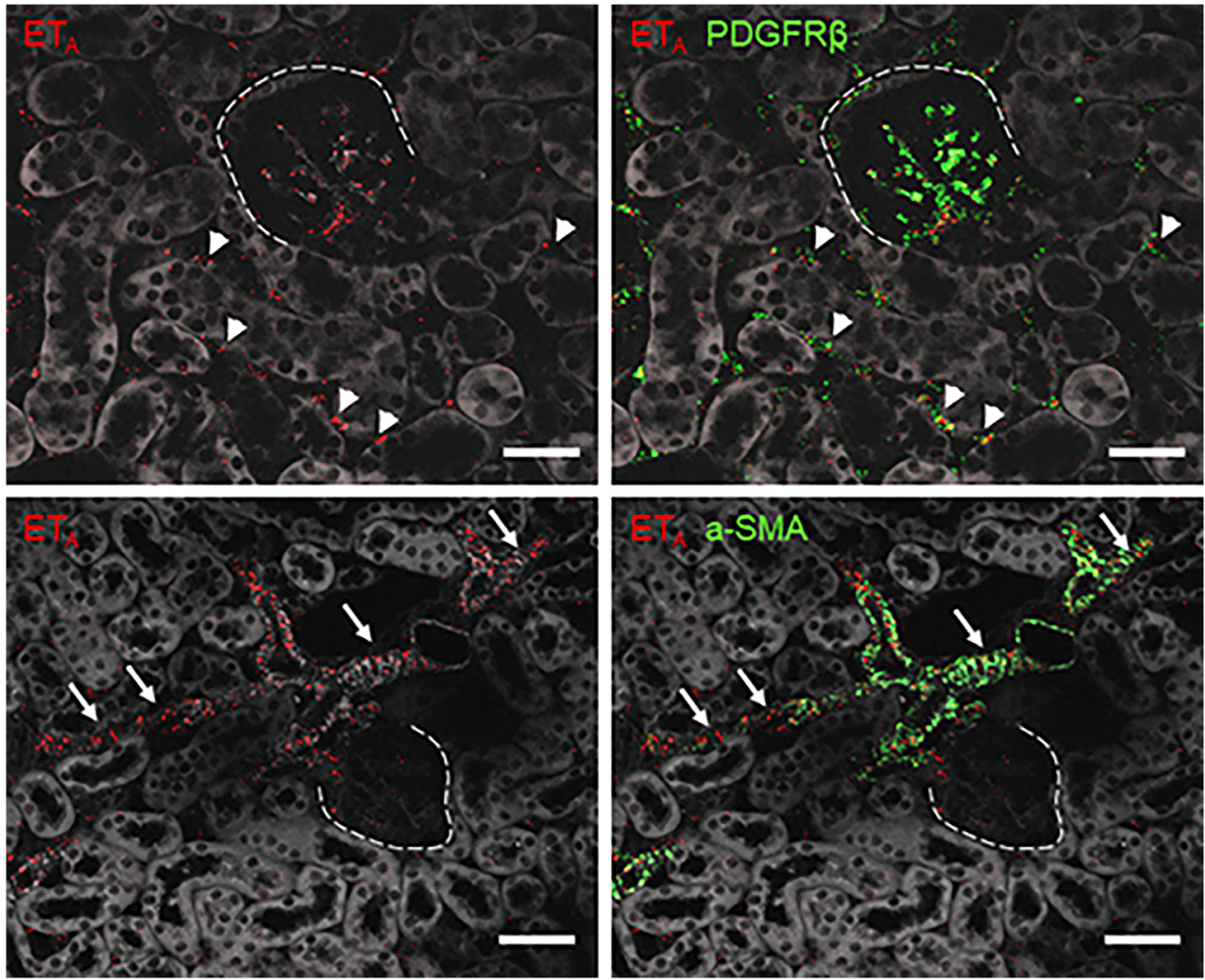

and UUO for 5 days led to a strong upregulation of $\alpha$-SMA expression (Fig. 11) and appeared in interstitial, fibroblast-like cells mainly in the outer and inner medulla of the kidney, whereas no significant difference could be observed between control and knockout mice. (Fig 11A, B). Immunohistochemical analysis of $\alpha$-SMA protein expression in basal and fibrotic kidneys of the two genotypes gave the same result (Suppl.Fig.2).

\section{Disruption of the ET signaling in stromal cells does not influence profibrotic gene expression in experimental kidney disease}

To examine a potential role of $\mathrm{ET}_{\mathrm{A}}-\mathrm{R}$ and $\mathrm{ET}_{\mathrm{B}}-\mathrm{R}$ expression in FoxD1-derived cells for deposition of extracellular matrix, we compared the expression of the key fibrotic marker collagen1a1 (Colla1), fibronectin, and tenascin $\mathrm{C}$ between control and ET-Ko mice. Experimental renal fibrosis led to 20- and 10-fold upregulation of Colla1 mRNA with no significant differences between genotypes (Fig. 12). Again, the analysis of the protein expression by immunohistochemistry showed no differences in Colla1 expression between the two genotypes (Suppl. Fig.3).

Adenine feeding and UUO also led to strong increases of fibronectin and tenascin $\mathrm{C}$ mRNA expressions which were also not different between control and endothelin receptor knockout mice (Fig. 12B).

\section{Disruption of the ET signaling in stromal cells does not affect proinflammatory gene expression in experimental kidney disease}

The influx of monocytes/macrophages and lymphocytes into the kidney in states of experimental renal disease leads to chronic interstitial inflammation and subsequent interstitial fibrosis $[60,66]$. We evaluated macrophage infiltration in fibrotic kidneys by analysis of F4/80 expression using RNAscope and real-time PCR. F4/80 is a well-known and widely used marker of murine macrophage populations. Both adenine treatment and UUO markedly elevated F4/80 mRNA expression in control and ET-Ko mice without any difference between genotypes (Fig. 13A,B). Additionally, we studied the expression of the chemokine fractalkine (Cx3CL1) and its receptor Cx3CR1 as a marker for inflammation which again did not show any difference between control and ET-Ko mice (Fig. 13B).

\section{Disruption of the ET signaling in stromal cells does not affect urinary ET-1 and albumin secretion in ex- perimental kidney disease}

Urinary ET-1 excretion showed no difference between controls and ET-Ko mice under basal conditions. Adenine treatment increased ET-1 excretion 2-fold in controls and 1.8-fold in ET-Ko mice, whereas UUO does not lead to a significant 


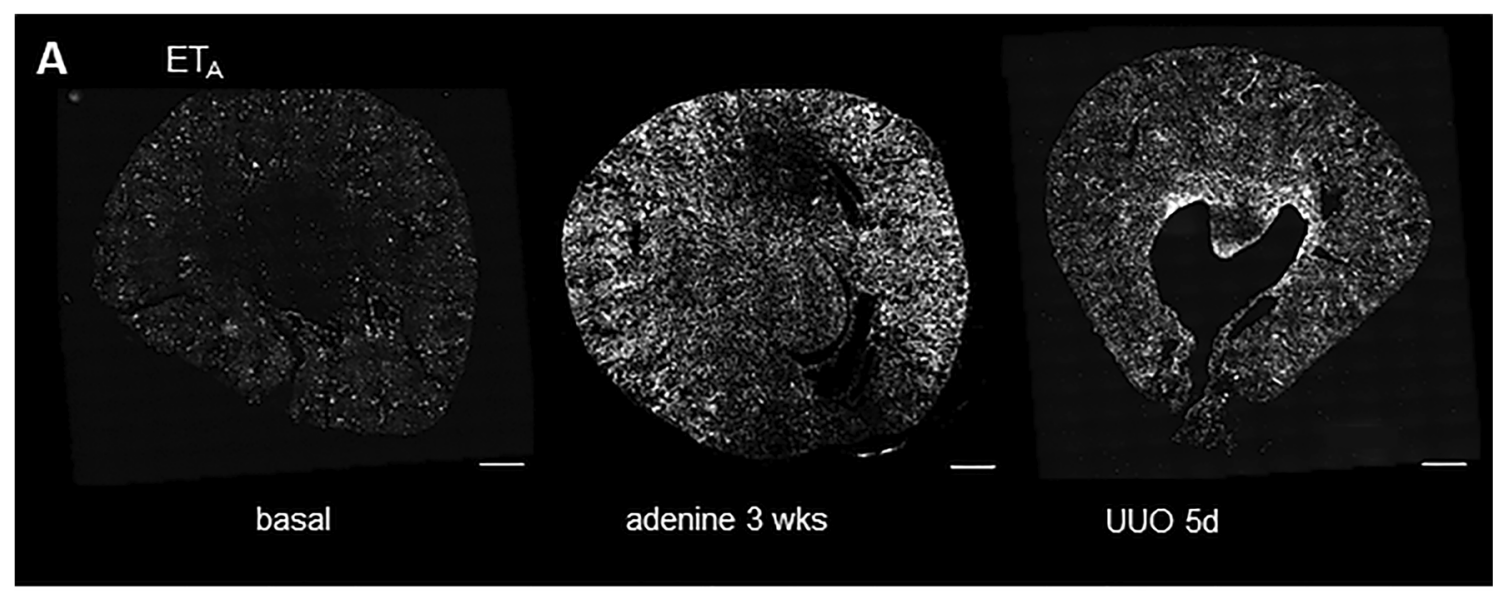

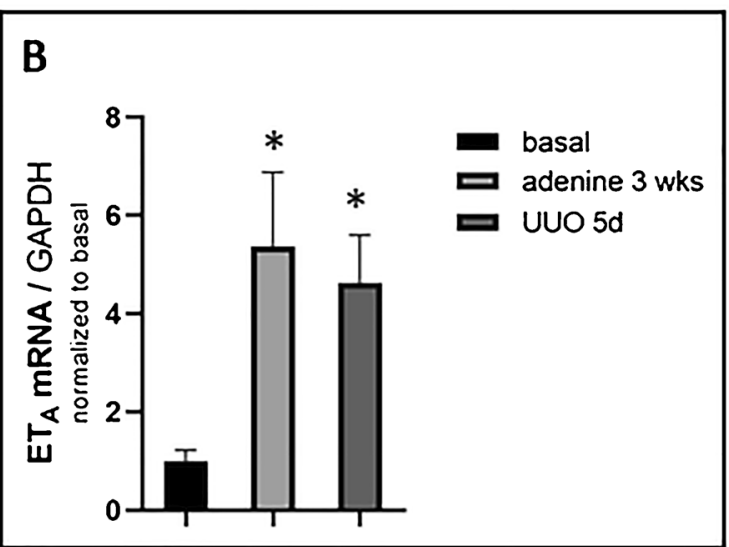

Fig. 5 ET receptor mRNA abundance in control mice under basal and pathological conditions. A RNAscope for $\mathrm{ET}_{\mathrm{A}}$ mRNA expression on whole kidney sections of control mice under basal conditions, after adenine feeding for 3 weeks and UUO for 5 days. Scale bars $=500 \mu \mathrm{m}$. B ET $\mathrm{A}_{\mathrm{A}}$ mRNA abundance of untreated mice (basal), after adenine feeding

increase in ET-1 concentrations in both genotypes (Table 6). No difference was observed between controls and ET-Ko mice with regard to urinary albumin excretion. Furthermore, neither adenine treatment nor UUO led to an increase in albumin excretion (Table 6).

\section{Discussion}

The aim of this study was to clarify the role of ET-1 signaling in stromal cells for the progression of renal fibrosis in two models of experimental renal disease. We found that adenine-induced nephropathy and unilateral ureter occlusion led to an upregulation of mainly tubular ET-1 expression and to an upregulation of $\mathrm{ET}_{\mathrm{A}}$ gene expression in the stromal cell compartment which includes also interstitial cells. Genetic ablation of endothelin receptors from the stromal cell compartment, however, did not change the upregulated expressions of profibrotic and proinflammatory markers during experimentally induced kidney fibrosis.

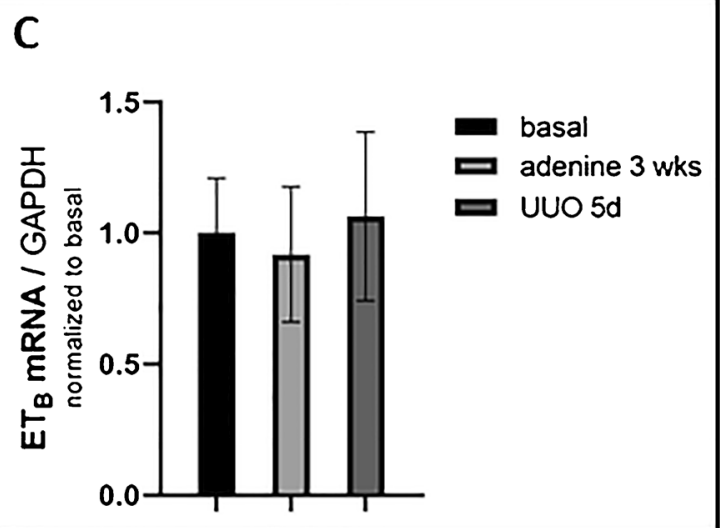

and after UUO for 5 days. Renal $\mathrm{ET}_{\mathrm{A}}$ mRNA levels increased about 5 fold in both experimental models. $\mathrm{C} \mathrm{ET}_{\mathrm{B}}$ mRNA abundance did not change in the pathological models. All data are means \pm SEM of 5-8 animals per condition. Single asterisk is $p<0,05$ compared to untreated animals. Note the different scales between data for $\mathrm{ET}_{\mathrm{A}}$ and $\mathrm{ET}_{\mathrm{B}}$ mRNAs

Our findings of an activation of the endothelin system in fibrotic kidney disease is in accordance with previous reports, which demonstrated either an enhanced ET-1 gene expression $[1,16,43,44]$ or an increased $\mathrm{ET}_{\mathrm{A}}$ gene expression $[9,16]$ in experimentally induced kidney fibrosis. We now extend these findings by showing the localization of increased ET-1 and $\mathrm{ET}_{\mathrm{A}}$ gene expression. Our data suggest that the enhanced expression of ET-1 mainly occurs in tubuli, while the expression of $\mathrm{ET}_{\mathrm{A}}$ almost exclusively occurs in the stromal cell compartment, which includes vascular smooth muscle cells, renin producing cells, mesangial cells, and resident interstitial cells. From these findings, we conclude that in states of kidney fibrosis, endothelin signaling in the stromal cell compartment and also in interstitial cells was enhanced. Our findings further show that genetic constitutive deletion of ET-R from the stroma cell population did not change the characteristic increases of profibrotic and proinflammatory gene expression during fibrotic disease, suggesting that endothelin signaling in stromal cells has less impact for the development of kidney fibrosis. On the first glance, this finding contrasts with a number of 

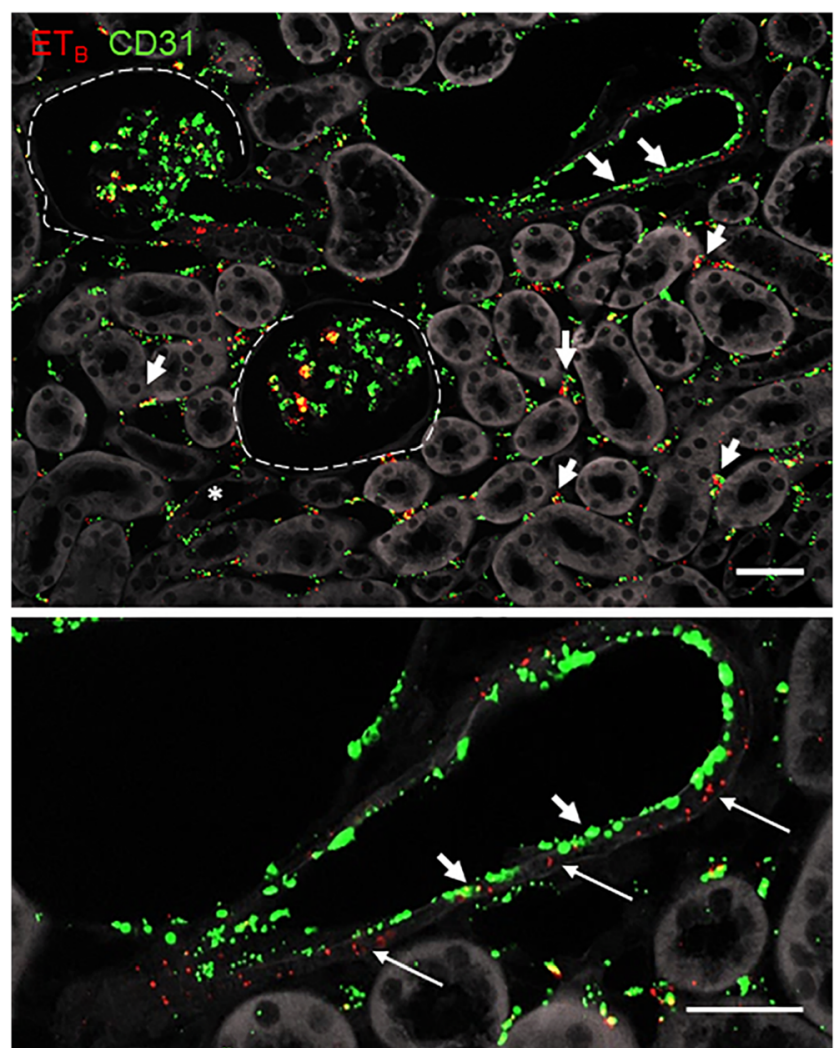

Fig. 6 Details of an RNAscope for $\mathrm{ET}_{\mathrm{B}}$ and $\mathrm{CD} 31 \mathrm{mRNA}$ on kidney sections of a control mouse. RNAscope for $\mathrm{ET}_{\mathrm{B}}$ (red) and CD31 (green) on kidney sections of control mice under basal conditions in the cortex. (upper panel). Asterisks indicate expression in tubular segments, arrowheads $\mathrm{ET}_{\mathrm{B}}$ expression in endothelial cells. Scale bar $=50 \mu \mathrm{m}$. The detailed view (lower panel) shows ETB expression in vascular smooth muscle cells. Arrows indicate expression in vascular smooth muscle cells, arrowheads in the endothelial layer. Scale bar $=50 \mu \mathrm{m}$

reports suggesting a profibrotic and proinflammatory role of endothelin during kidney disease. Our findings, moreover, appear to be in contrast with studies showing an attenuating effect of $\mathrm{ET}_{\mathrm{A}}$ antagonists in diabetes-related kidney damage $[13,23,53,58]$. Since in these latter studies endothelin antagonists were systemically administered and since the patho-mechanisms of diabetes-related kidney fibrosis may differ from those of tubulointerstitial fibrosis as examined in this study, the comparability of our results with those of the aforementioned studies is limited.

In this context, clinical trials should also be mentioned that show the therapeutic potential of $\mathrm{ET}_{\mathrm{A}}$ antagonists in kidney diseases and provide data that contradict our findings.

These trials performed with various ETA antagonists show reno-protective effects by reducing proteinuria in patients with chronic kidney disease and type 2 diabetes $[12,21,22,34,36$, $42,54,61]$ which shows us that the results from a selective, cell-specific deletion of the ET receptors in the animal model are hardly transferable to human kidney diseases.

An obvious explanation of the divergent findings could be a relevant role of the $\mathrm{ET}_{\mathrm{B}}$ for kidney fibrosis, which we mainly

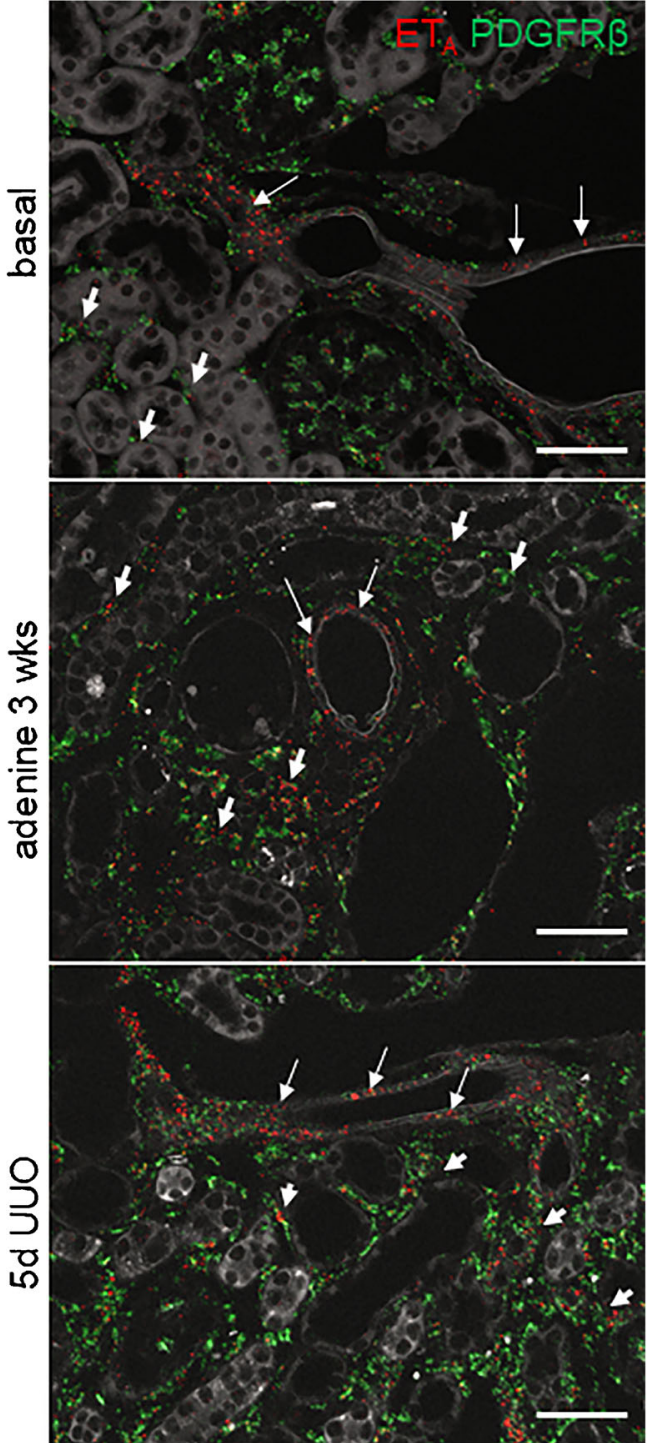

Fig. 7 Expression of $\mathrm{ET}_{\mathrm{A}}$ mRNA before and after induction of experimental renal fibrosis on control kidneys. RNAscope for $\mathrm{ET}_{\mathrm{A}}$ mRNA (red) on kidney sections of control kidneys with cohybridization of PDGFR- $\beta$ (green), under basal conditions, after 3week adenine treatment and 5-day UUO. Arrows indicate renal vessels, arrowheads $\mathrm{ET}_{\mathrm{A}}$ expression in interstitial mesenchymal cells. Scale bars $=$ $50 \mu \mathrm{m}$

localized in endothelial and tubular cells, what is in good accordance with previous findings [3, 38, 49, 67]. Although the expression of $\mathrm{ET}_{\mathrm{B}}$ mRNA did not change during kidney fibrosis, the increased expression of ET-1 mRNA in tubuli and endothelial cells could lead to an activation of endothelin signaling through $\mathrm{ET}_{\mathrm{B}}$, because $\mathrm{ET}-1$ is known to exert para- and autocrine effects. Indications to the relevance of $\mathrm{ET}_{\mathrm{B}}$ in fibrosis came from studies in which $\mathrm{ET}_{\mathrm{B}}$-specific antagonists prevented renal damage in experimental models of renal fibrosis [56]. It is conceivable therefore that tubular $\mathrm{ET}_{\mathrm{B}}$ signaling initiates or contributes to renal fibrosis such as epithelial to mesenchymal transformation $[8,56,59,68]$. Increased 
Table 4 Kidney developmental parameters under basal conditions in control and $\mathrm{ET}_{\mathrm{A}}{ }^{\text {flfl }} \mathrm{ET}_{\mathrm{B}}{ }^{\text {flfl }}$ FoxD $1^{\mathrm{Cre}+}$ mice. Value are means \pm SEM; $n=11-15$ mice

Table 5 Renal functional parameter under basal conditions in control and $\mathrm{ET}_{\mathrm{A}}{ }^{\text {flfl }} \mathrm{ET}_{\mathrm{B}}{ }^{\text {flfl }}$ FoxD1 ${ }^{\mathrm{Cre}+}$ mice. Value are means \pm SEM; $n=11-15$ mice.

\begin{tabular}{lll}
\hline Kidney developmental parameters & $\mathbf{E T}_{\mathbf{A}}{ }^{\text {flfl }} \mathbf{E T}_{\mathbf{B}}{ }^{\text {flf }}$ & $\mathbf{E T}_{\mathbf{A}}{ }^{\text {flfl }} \mathbf{E T}_{\mathbf{B}}{ }^{\text {flfl }} \mathbf{F o x D 1}{ }^{\text {Cre+ }}$ \\
\hline Body weight (g) & $23.6 \pm 0.69$ & $23.06 \pm 0.90$ \\
Two kidney-to-body weight ratio (\%) & $1.13 \pm 0.02$ & $1.11 \pm 0.02$ \\
\hline
\end{tabular}

\begin{tabular}{|c|c|c|}
\hline Renal functional parameters & $\mathbf{E T}_{\mathrm{A}}{ }^{\mathrm{flfl}} \mathbf{E T}_{\mathrm{B}}{ }^{\mathrm{flfl}}$ & $\mathbf{E T}_{\mathbf{A}}{ }^{\text {flfl }} \mathbf{E T}_{\mathbf{B}}{ }^{\text {flfl }}$ FoxD1 ${ }^{\text {Cre+ }}$ \\
\hline Systolic blood pressure (mmHg) & $128.5 \pm 1.10$ & $126.4 \pm 1.15$ \\
\hline Glomerular filtration rate/100g bw) ( $\mu 1 / \mathrm{min})$ & $1249.8 \pm 170.2$ & $1219.3 \pm 230.6$ \\
\hline Urine sodium $(\mathrm{mmol} / \mathrm{l})$ & $129.1 \pm 34.7$ & $153.8 \pm 63.1$ \\
\hline Urine potassium (mmol/l) & $232.4 \pm 63.5$ & $236.2 \pm 45,8$ \\
\hline Urine osmolality (mosmol/kg) & $1940.0 \pm 237.9$ & $1785.0 \pm 207.8$ \\
\hline Plasma urea concentration (mg/dl) & $73.08 \pm 1.99$ & $75.91 \pm 3.07$ \\
\hline Plasma creatinine concentration (mg/dl) & $0.75 \pm 0.02$ & $0.76 \pm 0.02$ \\
\hline Hematocrit (\%) & $54.9 \pm 1.4$ & $54.8 \pm 0.3$ \\
\hline Plasma erythropoietin (pg/ml) & $284.7 \pm 40.4$ & $316.7 \pm 72.7$ \\
\hline Plasma renin concentration (ng ANGI/ml*h) & $106.45 \pm 14.3$ & $80.60 \pm 7.11$ \\
\hline
\end{tabular}

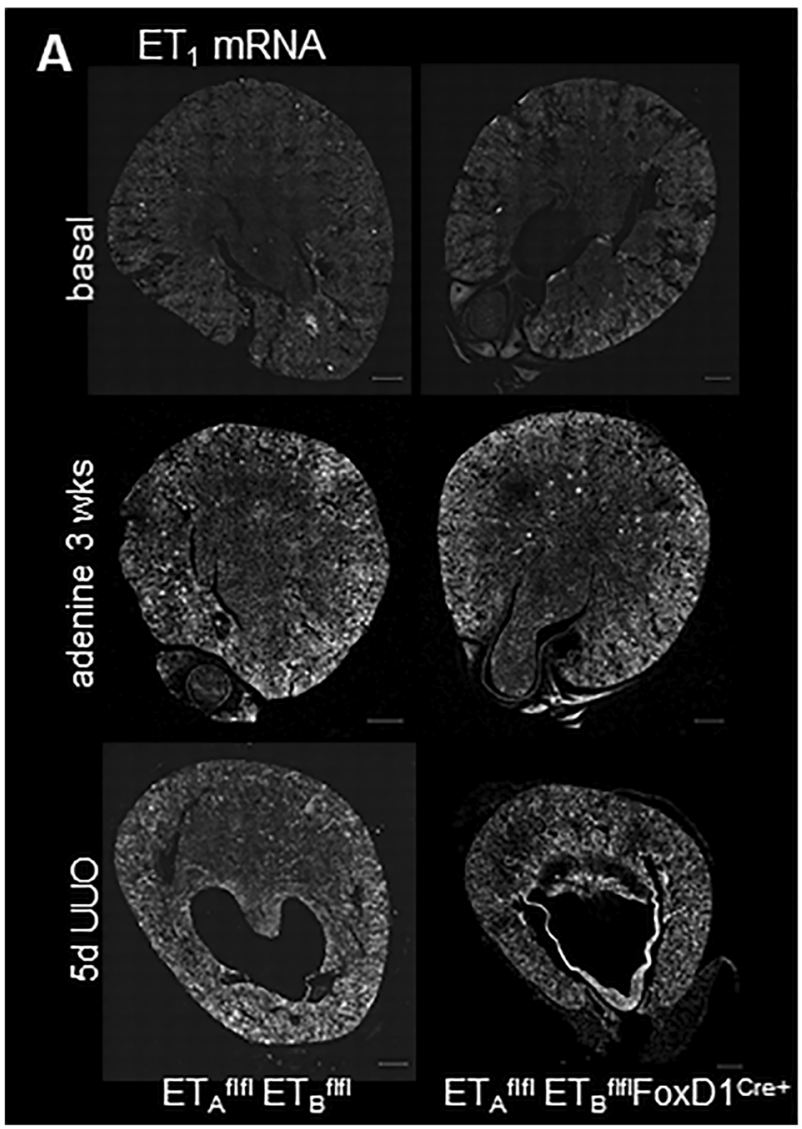

Fig. 8 ET-1 mRNA abundance in control and ET-Ko kidneys under basal and pathological conditions. A RNAscope showing ET-1 mRNA expression on whole kidney sections of both genotypes under basal conditions, after adenine feeding for 3 weeks and UUO for 5 days. There was no difference between the genotypes under any of the conditions analyzed. Scale bars $=500 \mu \mathrm{m}$. B Expression levels of ET-1 mRNA in
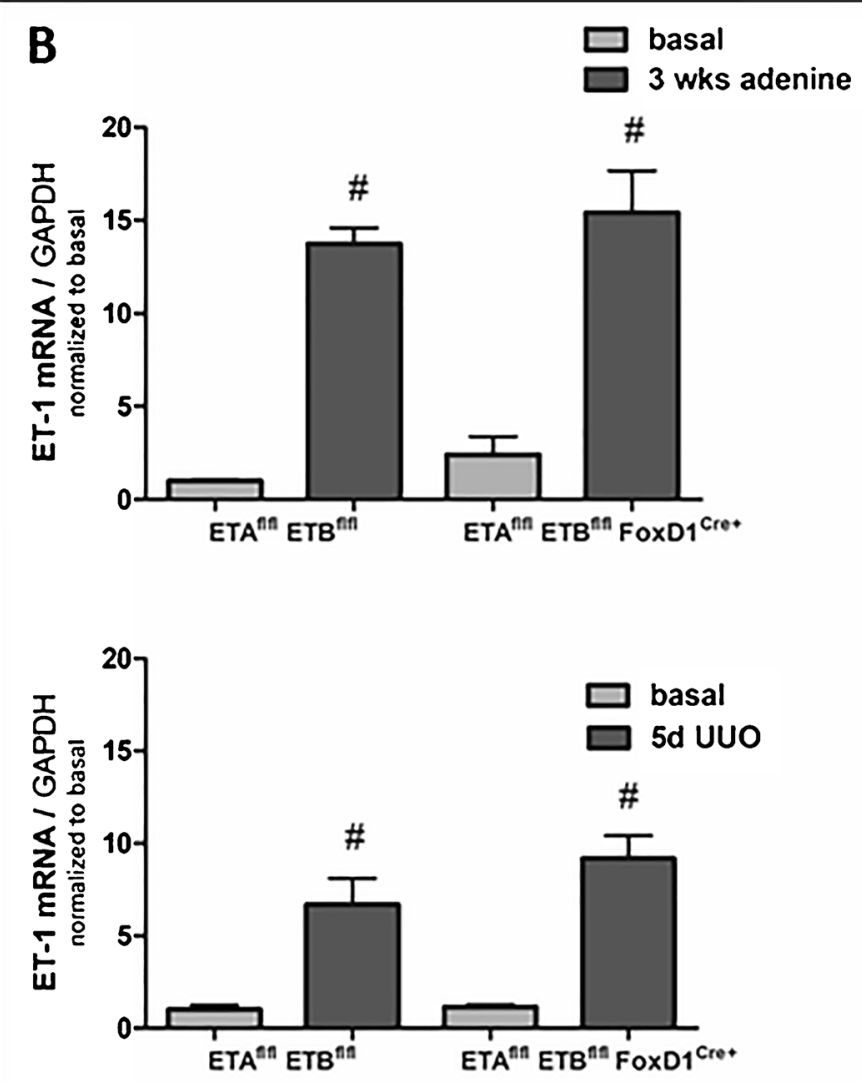

adenine-induced nephropathy and after 5-day UUO of control and ETKo mice. ET-1 mRNA showed a steep increase after 3-week adenine treatment and 5-day UUO with no difference between genotypes. All data are means \pm SEM of 5-8 animals per condition. \# is $p<0.05$ compared to the respective basal kidneys 


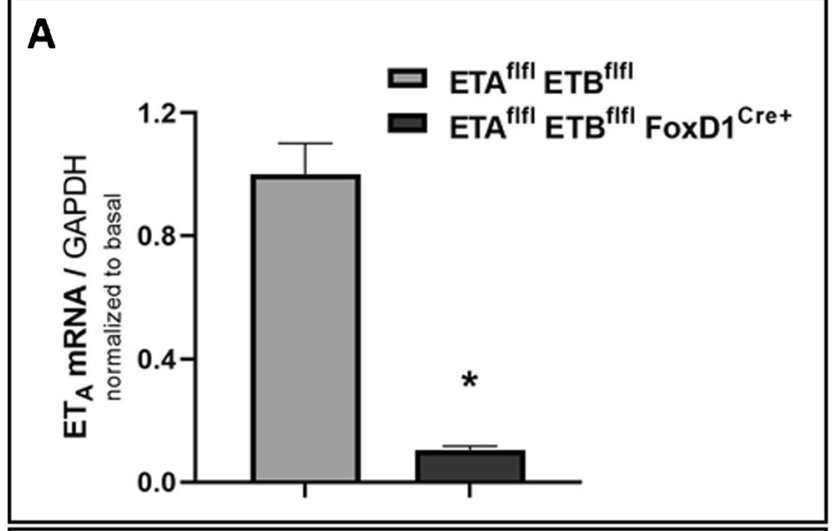

B
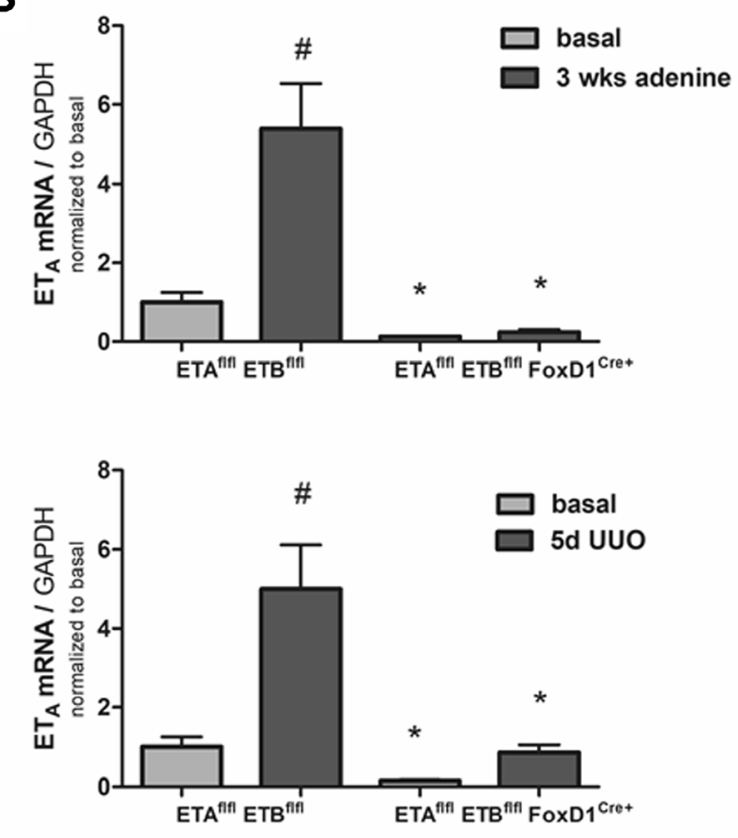

Fig. $9 \mathrm{ET}_{\mathrm{A}}$ mRNA abundance in control and ET-Ko kidneys under basal and pathological conditions. A Expression levels of $\mathrm{ET}_{\mathrm{A}}$ mRNA in control and ET-Ko mice. $\mathrm{ET}_{\mathrm{A}}$ mRNA decreased about $90 \%$ in knockout mice. All data are means \pm SEM of 10-12 mice per condition. Single asterisk is $p<0.05$ compared to untreated controls. B Expression levels of $\mathrm{ET}_{\mathrm{A}}$ mRNA in adenine-induced nephropathy (above) and after 5-day UUO (below) of control and ET-Ko mice. $\mathrm{ET}_{\mathrm{A}}$ mRNA showed a steep increase in kidneys of controls in both experimental models. In ET-Ko mice, $\mathrm{ET}_{\mathrm{A}}$ mRNA was not upregulated after adenine treatment and 5-day UUO. All data are means \pm SEM of 5-8 animals per condition. Single asterisk is $p<0.05$ compared to the respective controls. Number sign is $p$ $<0.05$ compared to the respective basal kidneys

activation of $\mathrm{ET}_{\mathrm{B}}-\mathrm{R}$ in tubuli or endothelial cells could also induce the production and release of cytokines, such as TGFß1, that induce matrix production in interstitial cells [4, 19, 47], or cytokines, like Cx3CL1 attracting inflammatory cell [69].

An interesting point to mention is that overexpression of ET-1 leads to inflammation of the kidney. Hocher et al. [24]
A

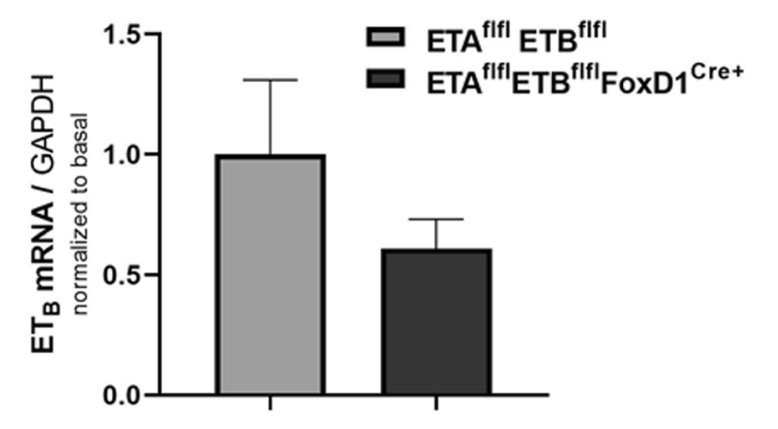

B
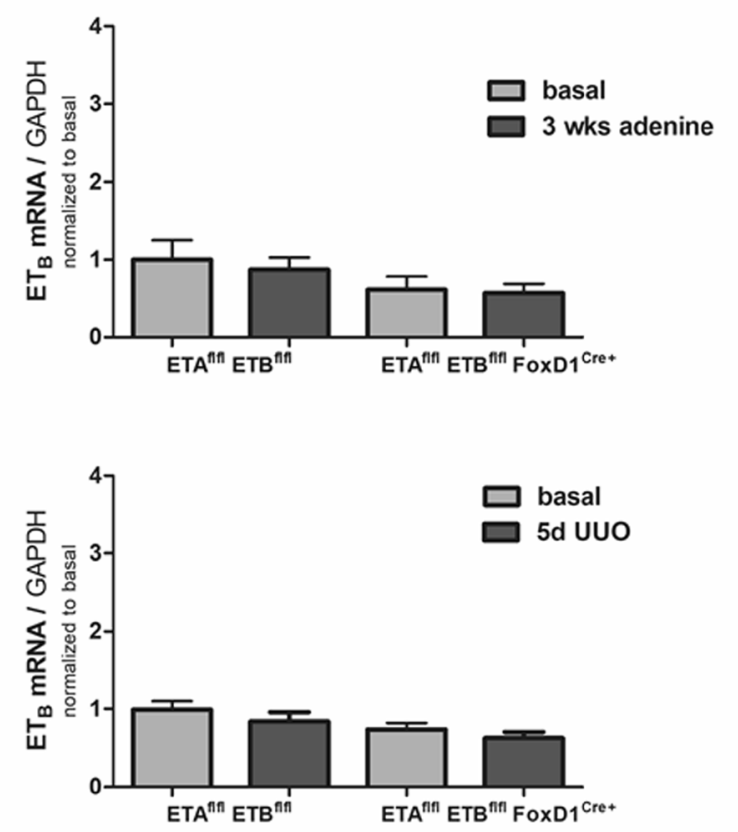

Fig. $10 \mathrm{ET}_{\mathrm{B}}$ mRNA abundance in control and ET-Ko kidneys under basal and pathological conditions. A Expression levels of $\mathrm{ET}_{\mathrm{B}} \mathrm{mRNA}$ in control and ET-Ko mice. $\mathrm{ET}_{\mathrm{B}}$ mRNA decreased about $25 \%$ in knockout mice. All data are means \pm SEM of 10-12 mice per condition. B Expression levels of $\mathrm{ET}_{\mathrm{B}} \mathrm{mRNA}$ in adenine-induced nephropathy (above) and after 5-day UUO (below) of control and ET-Ko mice. $\mathrm{ET}_{\mathrm{B}}$ mRNA remained unchanged in both experimental models. All data are means \pm SEM of 5-8 animals per condition

showed an increase in iNOS expression and an infiltration of CD4-positive lymphocytes and macrophages in the kidneys of ET-1 transgenic mice with overexpression of ET-1. Several studies have confirmed that renal inflammation is closely related to the formation of fibrosis, and it is assumed that macrophages promote inflammation in the early stages of kidney damage [17]. Therefore, when interpreting our results, we must also consider a connection between inflammation and fibrosis.

Another interesting aspect is provided by a work of Tsuprykov et al. in which ET-1 even shows antifibrotic effects in renal interstitial fibrosis and glomerulosclerosis [62]. This 

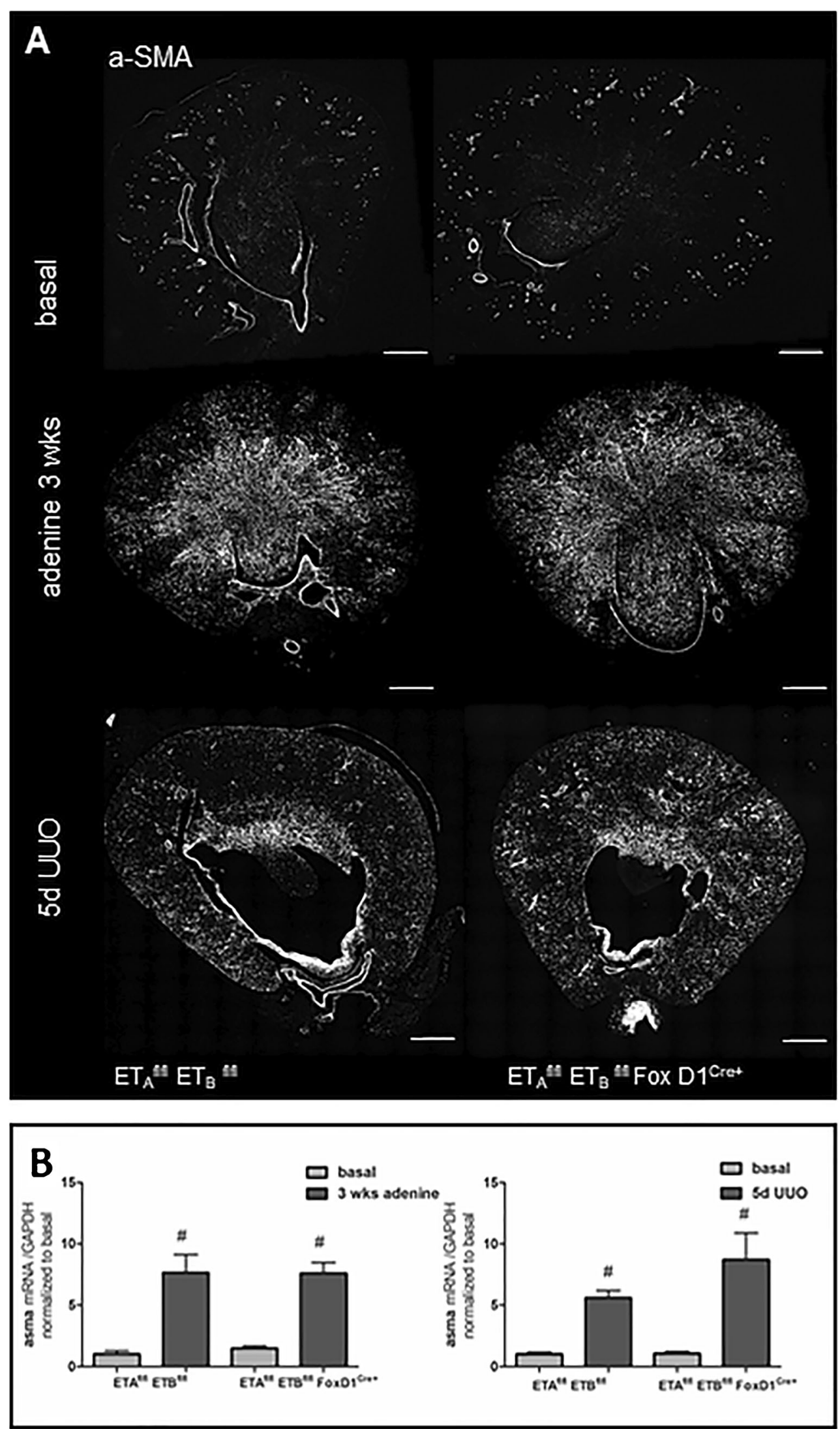
Fig. $11 \alpha$-SMA mRNA abundance in control and ET-Ko mice under basal and pathological conditions. A RNAscope showing $\alpha$-SMA mRNA on whole kidney sections of both genotypes under basal conditions, after adenine feeding for 3 weeks and UUO for 5 days. Scale bars = $500 \mu \mathrm{m}$. B Expression levels of $\alpha$-SMA mRNA in adenine-induced nephropathy (left) and after 5-day UUO (right) of control and ET-Ko mice. $\alpha$-SMA mRNA showed a steep increase in the kidneys of control mice in both experimental models without difference between genotypes. All data are means \pm SEM of 5-8 animals per condition. Number sign is $p<0.05$ compared to the respective basal kidneys

work shows that in eNOS -/- mice that develop renal interstitial and glomerular damage, the increase in expression of genes involved in renal fibrosis is markedly reduced by overexpression of ET-1.
Certainly, we cannot exclude that a minor residual expression of ET-R was sufficient to maintain an enhanced endothelin signaling in stromal cells, because Cre-lox recombination does normally not produce complete gene disruptions. However, in view of the marked changes of $\mathrm{ET}_{\mathrm{A}}$ mRNA in combination with unaffected mRNAs for profibrotic and proinflammatory markers, we consider this scenario as a less likely explanation.

Our data show the activation of the ET-system during the development of kidney fibrosis that includes an upregulation of ET-1 synthesis in endothelial and tubular cells but also the enhanced expression of $\mathrm{ET}_{\mathrm{A}}$ in FoxD1-derived mesenchymal progenitor cell population. Our findings further demonstrate that genetic deletion of ET-R in this compartment had no effect on development and progression of renal fibrosis. We now suspect that cellular processes other than the activation of fibroblasts play an essential role in renal fibrosis.

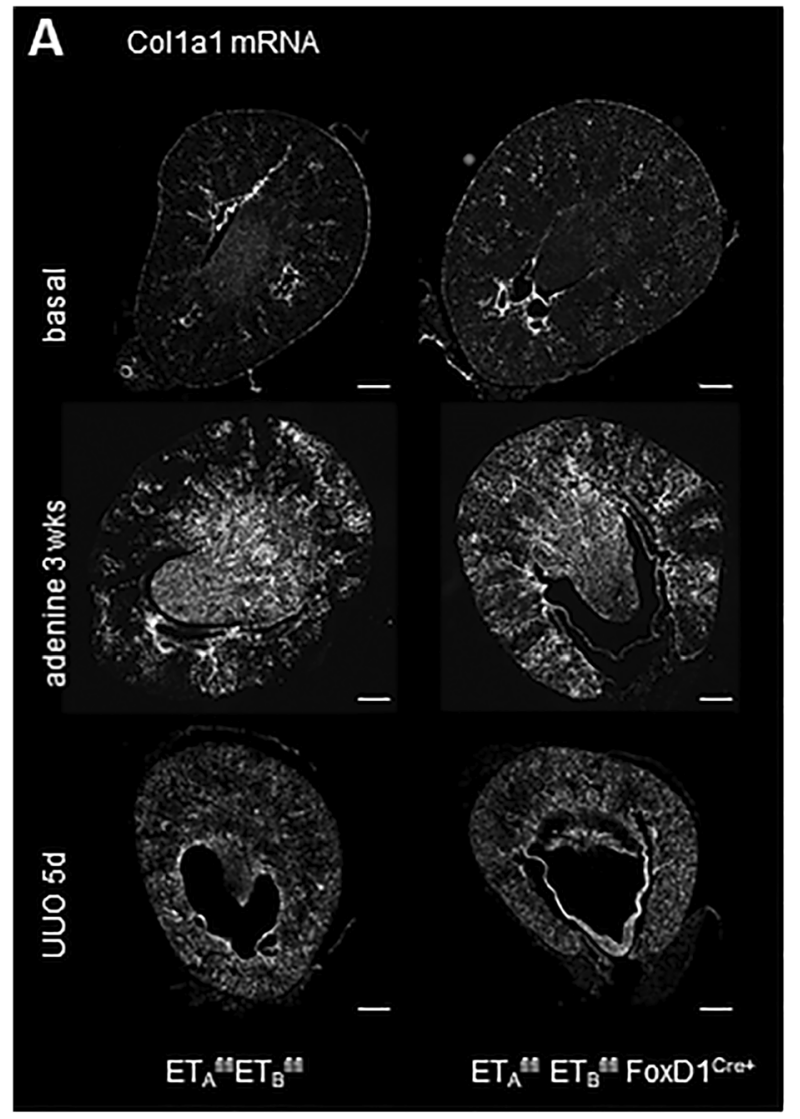

Fig. 12 mRNA abundance of profibrotic markers in control and ET-Ko mice under basal and pathological conditions. A RNAscope for Collal mRNA on whole kidney sections of both genotypes under basal conditions, after adenine feeding for 3 weeks and UUO for 5 days. Scale bars = $500 \mu \mathrm{m}$. B Expression levels of the fibrotic marker Colla1, fibronectin,

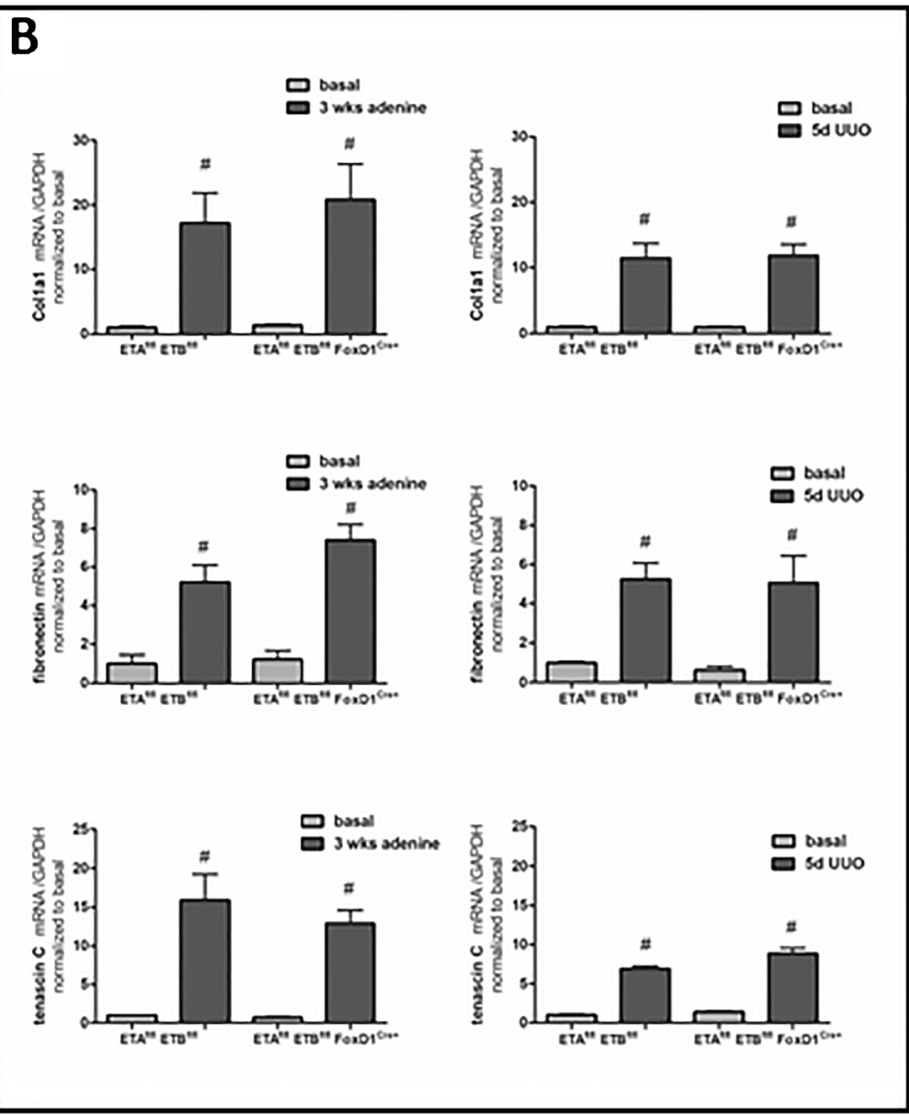

and tenascin $\mathrm{C}$ mRNA in adenine-induced nephropathy and after 5-day UUO of both genotypes. All markers showed a steep increase in the kidneys of both genotypes for each experimental model. All data are means \pm SEM of 5-8 animals per condition. Number sign is $p<0.05$ compared to the respective basal kidneys 


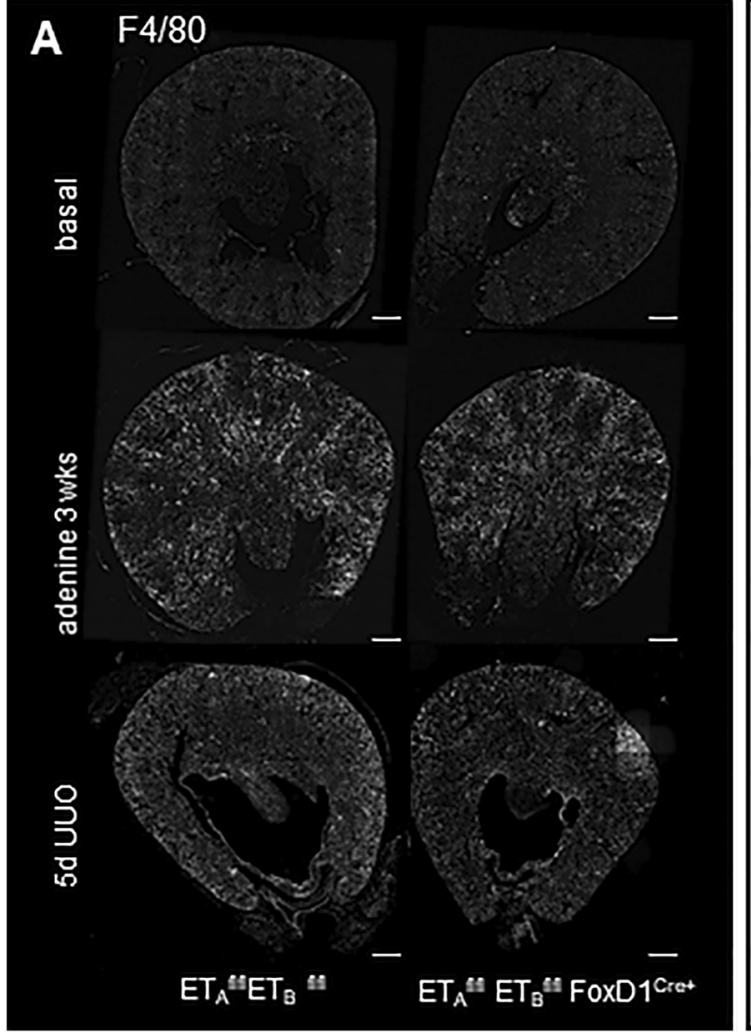

Fig. 13 mRNA abundance of proinflammatory markers in control and ET-Ko mice under basal and pathological conditions. A RNAscope for F4/80 mRNA on whole kidney sections of both genotypes under basal conditions, after adenine feeding for 3 weeks and UUO for 5 days. Scale bars $=500 \mu \mathrm{m}$. B Expression levels of F4/80, Cx3CR1, and Cx3CL1
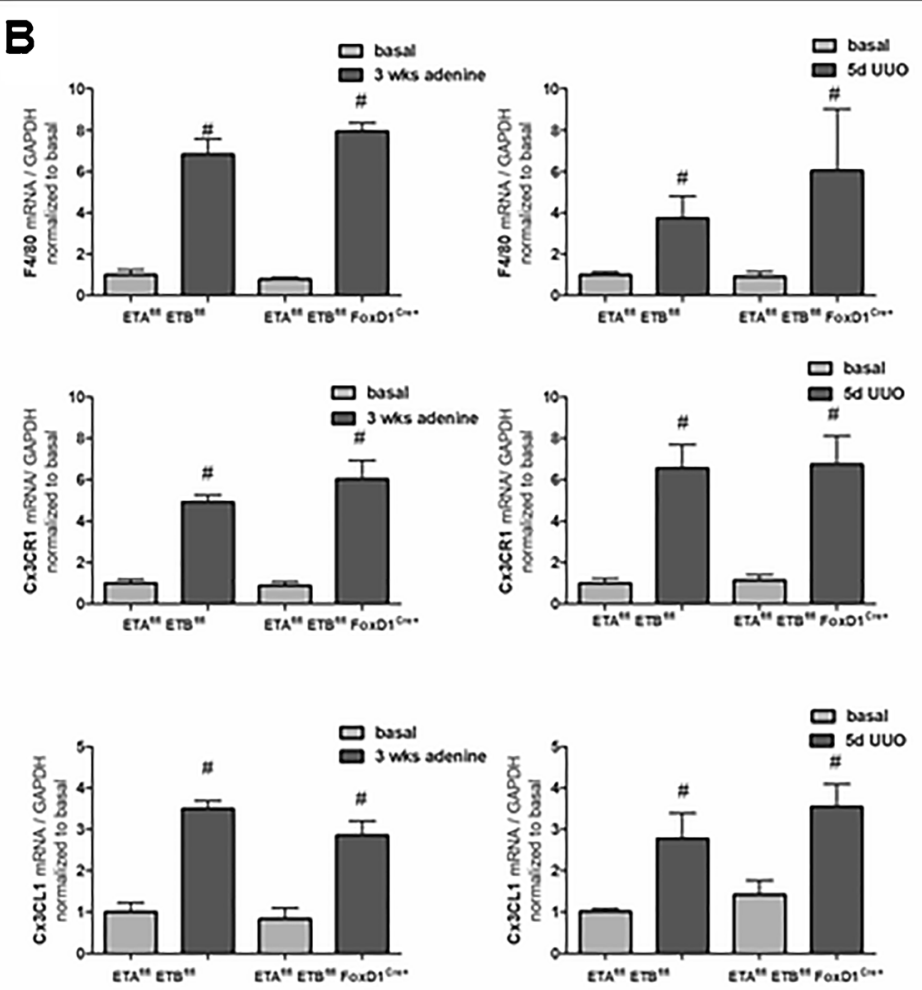

mRNA in adenine-induced nephropathy and after 5-day UUO of both genotypes. All markers showed a steep increase in kidneys of both genotypes for each experimental model. All data are means \pm SEM of 5-8 animals per condition. Number sign is $p<0.05$ compared to the respective basal kidneys

Table 6 Urinary ET-1 and albumin concentration in control and $\mathrm{ET}_{\mathrm{A}}{ }^{\text {flfl }} \mathrm{ET}_{\mathrm{B}}{ }^{\text {ffl }} \mathrm{FoxD1}{ }^{\mathrm{Cre}+}$ mice after adenine treatment and 5d UUO. Value are means \pm SEM; $n=4-7$ mice. Single asterisk is $\mathrm{p}<0.05$ compared to the respective controls

\begin{tabular}{|c|c|c|c|c|c|c|}
\hline & \multicolumn{3}{|l|}{$E T_{A}^{f l f l} E T_{B}^{f l f l}$} & \multicolumn{3}{|c|}{$E T_{A}^{f l f l} E T_{B}^{f l f l}$ FoxD1 ${ }^{\text {Cre }+}$} \\
\hline & basal & 3 wks adenine & 5-d UUO & Basal & 3 wks adenine & 5-d UUO \\
\hline ET-1 (pg/ml) & $0.66 \pm 0.07$ & $1.37 \pm 0.19 *$ & $0.77 \pm 0.11$ & $1.00 \pm 0.18$ & $1.79 \pm 0.29^{*}$ & $1.14 \pm 0.18$ \\
\hline albumin $(\mu \mathrm{g} / \mathrm{ml})$ & $14.52 \pm 1.45$ & $12.47 \pm 1.71$ & $11.16 \pm 1.96$ & $12.59 \pm 1.67$ & $16.03 \pm 2.46$ & $10.97 \pm 1.82$ \\
\hline
\end{tabular}

Supplementary Information The online version contains supplementary material available at https://doi.org/10.1007/s00424-021-02604-4.

Acknowledgements The authors would like to thank Ramona Steppan and Katharina Fizia for their expert technical assistance. We would like to thank Prof. Dr. M. Yanagisawa and Prof. Dr. M. Epstein for kindly providing $\mathrm{ET}_{\mathrm{A}}{ }^{\text {flf }}$ and $\mathrm{ET}_{\mathrm{B}}^{\text {fllt }}$ mice used for this study. Dr. T.H. Neder is currently with Klifovet AG, Munich, Germany.

Author contribution T.H.N. and C.W. conceived and designed research. T.H.N. and C.W. performed experiments, analyzed data and interpreted results of experiments, and edited and revised the manuscript. K.A.E.B., M.A.A.F., and J.S. approved the final version of manuscript.
Funding Open Access funding enabled and organized by Projekt DEAL. This work was supported by grants from the German Research Foundation (SFB 1350).

\section{Declarations}

Conflict of interest The authors declare no competing interests.

Open Access This article is licensed under a Creative Commons Attribution 4.0 International License, which permits use, sharing, adaptation, distribution and reproduction in any medium or format, as long as you give appropriate credit to the original author(s) and the source, provide a link to the Creative Commons licence, and indicate if changes were made. The images or other third party material in this article are included in the article's Creative Commons licence, unless indicated otherwise in a 
credit line to the material. If material is not included in the article's Creative Commons licence and your intended use is not permitted by statutory regulation or exceeds the permitted use, you will need to obtain permission directly from the copyright holder. To view a copy of this licence, visit http://creativecommons.org/licenses/by/4.0/.

\section{References}

1. Arfian N, Emoto N, Vignon-Zellweger N, Nakayama K, Yagi K, Hirata K (2012) ET-1 deletion from endothelial cells protects the kidney during the extension phase of ischemia/reperfusion injury. Biochem Biophys Res Commun 425:443-449. https://doi.org/10. 1016/j.bbrc.2012.07.121

2. Arfian N, Suzuki Y, Hartopo AB, Anggorowati N, Nugrahaningsih DAA, Emoto N (2020) Endothelin converting enzyme-1 (ECE-1) deletion in association with endothelin-1 downregulation ameliorates kidney fibrosis in mice. Life Sci 258:118223. https://doi.org/ 10.1016/j.lfs.2020.118223

3. Bailly C (2000) Effect of luminal atrial natriuretic peptide on chloride reabsorption in mouse cortical thick ascending limb: inhibition by endothelin. J Am Soc Nephrol 11:1791-1797. https://doi.org/10. 1681/ASN.V11101791

4. Barton M, Yanagisawa M (2008) Endothelin: 20 years from discovery to therapy. Can J Physiol Pharmacol 86:485-498. https:// doi.org/10.1139/Y08-059

5. Benigni A, Zola C, Corna D, Orisio S, Facchinetti D, Benati L, Remuzzi G (1996) Blocking both type A and B endothelin receptors in the kidney attenuates renal injury and prolongs survival in rats with remnant kidney. Am J Kidney Dis 27:416-423. https:// doi.org/10.1016/s0272-6386(96)90366-2

6. Buchtler S, Grill A, Hofmarksrichter S, Stöckert P, SchiechlBrachner G, Rodriguez Gomez M, Neumayer S, Schmidbauer K, Talke Y, Klinkhammer BM, Boor P, Medvinsky A, Renner K, Castrop H, Mack M (2018) cellular origin and functional relevance of collagen I production in the kidney. J Am Soc Nephrol 29:18591873. https://doi.org/10.1681/ASN.2018020138

7. Bülow RD, Boor P (2019) Extracellular matrix in kidney fibrosis: more than just a scaffold. J Histochem Cytochem 67:643-661. https://doi.org/10.1369/0022155419849388

8. Carew RM, Wang B, Kantharidis P (2012) The role of EMT in renal fibrosis. Cell Tissue Res 347:103-116. https://doi.org/10. 1007/s00441-011-1227-1

9. Chang YK, Choi H, Jeong JY, Na KR, Lee KW, Choi DE (2016) Co-inhibition of angiotensin II receptor and endothelin-1 attenuates renal injury in unilateral ureteral obstructed mice. Kidney Blood Press Res 41:450-459. https://doi.org/10.1159/000443446

10. Chevalier RL, Forbes MS, Thornhill BA (2009) Ureteral obstruction as a model of renal interstitial fibrosis and obstructive nephropathy. Kidney Int 75:1145-1152. https://doi.org/10.1038/ki.2009.86

11. Chomczynski P, Sacchi N (1987) Single-step method of RNA isolation by acid guanidinium thiocyanate-phenol-chloroform extraction. Anal Biochem 162(1):156-159. https://doi.org/10.1006/abio. 1987.9999

12. Dhaun N, Goddard J, Webb DJ (2011) Endothelin antagonism in patients with nondiabetic chronic kidney disease. Contrib Nephrol 172:243-254. https://doi.org/10.1159/000328704

13. Ding SS, Qiu C, Hess P, Xi JF, Zheng N, Clozel M (2003) Chronic endothelin receptor blockade prevents both early hyperfiltration and late overt diabetic nephropathy in the rat. J Cardiovasc Pharmacol 42:48-54. https://doi.org/10.1097/00005344-200307000-00008

14. Druckenbrod NR, Powers PA, Bartley CR, Walker JW, Epstein ML (2008) Targeting of endothelin receptor-B to the neural crest. Genesis 46:396-400. https://doi.org/10.1002/dvg.20415
15. Falke LL, Gholizadeh S, Goldschmeding R, Kok RJ, Nguyen TQ (2015) Diverse origins of the myofibroblast - implications for kidney fibrosis. Nat Rev Nephrol 11:233-244. https://doi.org/10.1038/ nrneph.2014.246

16. Feldman DL, Mogelesky TC, Chou M, Jeng AY (2000) Enhanced expression of renal endothelin-converting enzyme- 1 and endothelin-A-receptor mRNA in rats with interstitial fibrosis following ureter ligation. J Cardiovasc Pharmacol 36:S255-S259. https://doi.org/10.1097/00005344-200036051-0007

17. Freytes DO, Kang JW, Marcos-Campos I, Vunjak-Novakovic G (2013) Macrophages modulate the viability and growth of human mesenchymal stem cells. J Cell Biochem 114:220-229. https://doi. org/10.1002/jcb. 24357

18. Gomez IG, Duffield JS (2011) The FOXD1 lineage of kidney perivascular cells and myofibroblasts: functions and responses to injury. Kidney Int Suppl 4:26-33. https://doi.org/10.1038/kisup. 2014.6

19. Gómez-Garre D, Ruiz-Ortega M, Ortego M, Largo R, LópezArmada MJ, Plaza JJ, González E, Egido J (1996) Effects and interactions of endothelin-1 and angiotensin II on matrix protein expression and synthesis and mesangial cell growth. Hypertension 27:885-892. https://doi.org/10.1161/01.hyp.27.4. 885

20. Grande MT, López-Novoa JM (2009) Fibroblast activation and myofibroblast generation in obstructive nephropathy. Nat Rev Nephrol 5:319-328. https://doi.org/10.1038/nrneph.2009.74

21. Heerspink HJL, Andress DL, Bakris G, Brennan JJ, Correa-Rotter R, Hou FF, Kitzman DW, Kohan D, Makino H, McMurray J, Perkovic V, Tobe S, Wigderson M, Yi T, Parving HH, de Zeeuw D (2018) Baseline characteristics and enrichment results from the SONAR trial. Diabetes Obes Metab 20:1829-1835. https://doi.org/ 10.1111/dom. 13315

22. Heerspink HJL, Parving HH, Andress DL, Bakris G, Correa-Rotter R, Hou FF, Kitzman DW, Kohan D, Makino H, McMurray JJV, Melnick JZ, Miller MG, Pergola PE, Perkovic V, Tobe S, Yi T, Wigderson M, de Zeeuw D (2019) Atrasentan and renal events in patients with type 2 diabetes and chronic kidney disease (SONAR): a double-blind, randomised, placebo-controlled trial. SONAR Committees and Investigators. Lancet 11:1937-1947. https://doi. org/10.1016/S0140-6736(19)30772-X

23. Hocher B, Schwarz A, Reinbacher D, Jacobi J, Lun A, Priem F, Bauer C, Neumayer HH, Raschack M (2001) Effects of endothelin receptor antagonists on the progression of diabetic nephropathy. Nephron 87:161-169. https://doi.org/10.1159/000045906

24. Hocher B, Schwarz A, Slowinski T, Bachmann S, Pfeilschifter J, Neumayer HH, Bauer C (2004) In-vivo interaction of nitric oxide and endothelin. J Hypertens 22:111-119. https://doi.org/10.1097/ 00004872-200401000-00020

25. Hocher B, Thöne-Reineke C, Rohmeiss P, Schmager F, Slowinski T, Burst V, Siegmund F, Quertermous T, Bauer C, Neumayer HH, Schleuning WD, Theuring F (1997) Endothelin-1 transgenic mice develop glomerulosclerosis, interstitial fibrosis, and renal cysts but not hypertension. J Clin Invest 99:1380-1389. https://oi.org/10. 1172/JCI1 19297

26. Houde M, Desbiens L, D'Orléans-Juste P (2016) endothelin-1: biosynthesis, signaling and vasoreactivity. Adv Pharmacol 77:143175. https://doi.org/10.1016/bs.apha.2016.05.002

27. Humphreys BD (2018) Mechanisms of renal fibrosis. Annu Rev Physiol 80:309-326. https://doi.org/10.1146/annurev-physiol022516-034227

28. Humphreys BD, Lin SL, Kobayashi A, Hudson TE, Nowlin BT, Bonventre JV, Valerius MT, McMahon AP, Duffield JS (2010) Fate tracing reveals the pericyte and not epithelial origin of myofibroblasts in kidney fibrosis. Am J Pathol 176:85-97. https:// doi.org/10.2353/ajpath.2010.090517 
29. Jia T, Olauson H, Lindberg K, Amin R, Edvardsson K, Lindholm B, Andersson G, Wernerson A, Sabbagh Y, Schiavi S, Larsson TE (2013) A novel model of adenine-induced tubulointerstitial nephropathy in mice. BMC Nephrol 14:116. https://doi.org/10.1186/ 1471-2369-14-116

30. Kedzierski RM, Grayburn PA, Kisanuki YY, Williams CS, Hammer RE, Richardson JA, Schneider MD, Yanagisawa M (2003) Cardiomyocyte-specific endothelin A receptor knockout mice have normal cardiac function and an unaltered hypertrophic response to angiotensin II and isoproterenol. Mol Cell Biol 23: 8226-8232. https://doi.org/10.1128/MCB.23.22.8226-8232.2003

31. Kendall RT, Feghali-Bostwick CA (2014) Fibroblasts in fibrosis: novel roles and mediators. Front Pharmacol 5:123. https://doi.org/ 10.3389/fphar.2014.00123

32. Klinkhammer BM, Djudjaj S, Kunter U, Palsson R, Edvardsson VO, Wiech T, Thorsteinsdottir M, Hardarson S, Foresto-Neto O, Mulay SR, Moeller MJ, Jahnen-Dechent W, Floege J, Anders HJ, Boor P (2020) Cellular and molecular mechanisms of kidney injury in 2,8-dihydroxyadenine nephropathy. J Am Soc Nephrol 31:799816. https://doi.org/10.1681/ASN.2019080827

33. Kohan DE (1997) Endothelins in the normal and diseased kidney. Am J Kidney Dis 29:2-26. https://doi.org/10.1016/s0272-6386(97) 90004-4

34. Kohan DE, Pritchett Y, Molitch M, Wen S, Garimella T, Audhya P, Andress DL (2011) Addition of atrasentan to renin-angiotensin system blockade reduces albuminuria in diabetic nephropathy. J Am Soc Nephrol 22:763-772. https://doi.org/10.1681/ASN. 2010080869

35. Kon V, Hunley TE, Fogo A (1995) Combined antagonism of endothelin $\mathrm{A} / \mathrm{B}$ receptors links endothelin to vasoconstriction whereas angiotensin II effects fibrosis. Studies in chronic cyclosporine nephrotoxicity in rats. Transplantation 60:89-95. https:// doi.org/10.1097/00007890-199507150-00017

36. Koomen JV, Stevens J, Bakris G, Correa-Rotter R, Hou FF, Kitzman DW, Kohan D, Makino H, McMurray JJV, Parving HH, Perkovic V, Tobe SW, de Zeeuw D, Heerspink HJL (2021) Interindividual variability in atrasentan exposure partly explains variability in kidney protection and fluid retention responses: a post hoc analysis of the SONAR trial. Diabetes Obes Metab 23:561568. https://doi.org/10.1111/dom.14252

37. Kuppe C, Ibrahim MM, Kranz J, Zhang X, Ziegler S, Perales-Patón J, Jansen J, Reimer KC, Smith JR, Dobie R, Wilson-Kanamori JR, Halder M, Xu Y, Kabgani N, Kaesler N, Klaus M, Gernhold L, Puelles VG, Huber TB, Boor P, Menzel S, Hoogenboezem RM, Bindels EMJ, Steffens J, Floege J, Schneider RK, Saez-Rodriguez J, Henderson NC, Kramann R (2021) Decoding myofibroblast origins in human kidney fibrosis. Nature 589:281-286. https://doi. org/10.1038/s41586-020-2941-1

38. Laghmani K, Preisig PA, Moe OW, Yanagisawa M, Alpern RJ (2001) Endothelin-1/endothelin-B receptor-mediated increases in NHE3 activity in chronic metabolic acidosis. J Clin Invest 107: 1563-1569. https://doi.org/10.1172/JCI11234

39. LeBleu VS, Taduri G, O'Connell J, Teng Y, Cooke VG, Woda C, Sugimoto H, Kalluri R (2013) Origin and function of myofibroblasts in kidney fibrosis. Nat Med 19:1047-1053. https:// doi.org/10.1038/nm.3218

40. Lin EE, Sequeira-Lopez ML, Gomez RA (2014) RBP-J in FOXD1 + renal stromal progenitors is crucial for the proper development and assembly of the kidney vasculature and glomerular mesangial cells. Am J Physiol Ren Physiol 306:F249-F258. https://doi.org/ 10.1152/ajprenal.00313.2013

41. Lin SL, Kisseleva T, Brenner DA, Duffield JS (2008) Pericytes and perivascular fibroblasts are the primary source of collagenproducing cells in obstructive fibrosis of the kidney. Am J Pathol 173:1617-1627. https://doi.org/10.2353/ajpath.2008.080433
42. Mann JF, Green D, Jamerson K, Ruilope LM, Kuranoff SJ, Littke T, Viberti G (2010) Avosentan for overt diabetic nephropathy. ASCEND Study Group. J Am Soc Nephrol 21:527-535. https:// doi.org/10.1681/ASN.2009060593

43. Morales-Loredo H, Jones D, Barrera A, Mendiola PJ, Garcia J, Pace C, Murphy M, Kanagy NL, Gonzalez Bosc LV (2019) A dual blocker of endothelin $\mathrm{A} / \mathrm{B}$ receptors mitigates hypertension but not renal dysfunction in a rat model of chronic kidney disease and sleep apnea. Am J Physiol Ren Physiol 316:F1041-F1052. https://doi. org/10.1152/ajprenal.00018.2019

44. Moridaira K, Morrissey J, Fitzgerald M, Guo G, McCracken R, Tolley T, Klahr S (2003) ACE inhibition increases expression of the ETB receptor in kidneys of mice with unilateral obstruction. Am J Physiol Ren Physiol 284:F209-F217. https://doi.org/10.1152/ ajprenal.00352.2001

45. Nakamura T, Ebihara I, Fukui M, Tomino Y, Koide H (1995) Effect of a specific endothelin receptor A antagonist on mRNA levels for extracellular matrix components and growth factors in diabetic glomeruli. Diabetes 44:895-899. https://doi.org/10.2337/ diab.44.8.895

46. Neelisetty S, Alford C, Reynolds K, Woodbury L, Nlandu-Khodo S, Yang H, Fogo AB, Hao CM, Harris RC, Zent R, Gewin L (2015) Renal fibrosis is not reduced by blocking transforming growth factor- $\beta$ signaling in matrix-producing interstitial cells. Kidney Int 88:503-514. https://doi.org/10.1038/ki.2015.51

47. Ong AC, Jowett TP, Firth JD, Burton S, Kitamura M, Fine LG (1994) Human tubular-derived endothelin in the paracrine regulation of renal interstitial fibroblast function. Exp Nephrol 2:134

48. Orth SR, Odoni G, Amann K, Strzelczyk P, Raschack M, Ritz E (1999) The ET(A) receptor blocker LU 135252 prevents chronic transplant nephropathy in the "Fisher to Lewis" model. J Am Soc Nephrol 10:387-391. https://doi.org/10.1681/ASN.V102387

49. Plato CF, Pollock DM, Garvin JL (2000) Endothelin inhibits thick ascending limb chloride flux via ET(B) receptor-mediated NO release. Am J Physiol Ren Physiol 279:F326-F333. https://doi.org/ 10.1152/ajprenal.2000.279.2.F326

50. Pollock DM, Keith TL, Highsmith RF (1995) Endothelin receptors and calcium signaling. FASEB J 9:1196-1204. https://doi.org/10. 1096/fasebj.9.12.7672512

51. Rahman A, Yamazaki D, Sufiun A, Kitada K, Hitomi H, Nakano D, Nishiyama A (2018) A novel approach to adenine-induced chronic kidney disease associated anemia in rodents. PLoS One 13: e0192531. https://doi.org/10.1371/journal.pone.0192531

52. Sandoval YH, Atef ME, Levesque LO, Li Y, Anand-Srivastava MB (2014) Endothelin-1 signaling in vascular physiology and pathophysiology. Curr Vasc Pharmacol 12:202-214. https://doi.org/10. 2174/1570161112666140226122054

53. Sasser JM, Sullivan JC, Hobbs JL, Yamamoto T, Pollock DM, Carmines PK, Pollock JS (2007) Endothelin A receptor blockade reduces diabetic renal injury via an anti-inflammatory mechanism. J Am Soc Nephrol 18:143-154. https://doi.org/10.1681/ASN. 2006030208

54. Schievink B, de Zeeuw D, Smink PA, Andress D, Brennan JJ, Coll B, Correa-Rotter R, Hou FF, Kohan D, Kitzman DW, Makino H, Parving HH, Perkovic V, Remuzzi G, Tobe S, Toto R, Hoekman J, Lambers Heerspink HJ (2016) Prediction of the effect of atrasentan on renal and heart failure outcomes based on short-term changes in multiple risk markers. Eur J Prev Cardiol 23:758-768. https://doi. org/10.1177/2047487315598709

55. Schrimpf C, Duffield JS (2011) Mechanisms of fibrosis: the role of the pericyte. Curr Opin Nephrol Hypertens 20:297-305. https://doi. org/10.1097/MNH.0b013e328344c3d4

56. Seccia TM, Caroccia B, Gioco F, Piazza M, Buccella V, Guidolin D, Guerzoni E, Montini B, Petrelli L, Pagnin E, Ravarotto V, Belloni AS, Calò LA, Rossi GP (2016) Endothelin-1 drives epithelial-mesenchymal transition in hypertensive 
nephroangiosclerosis. J Am Heart Assoc 5:e003888. https://doi. org/10.1161/JAHA.116.003888

57. Sequeira Lopez ML, Gomez RA (2011) Development of the renal arterioles. J Am Soc Nephrol 22:2156-2165. https://doi.org/10. 1681/ASN.2011080818

58. Spires D, Poudel B, Shields CA, Pennington A, Fizer B, Taylor L, McPherson KC, Cornelius DC, Williams JM (2018) Prevention of the progression of renal injury in diabetic rodent models with preexisting renal disease with chronic endothelin A receptor blockade. Am J Physiol Ren Physiol 315:F977-F985. https://doi.org/10. 1152/ajprenal.00182.2018

59. Tang L, Li H, Gou R, Cheng G, Guo Y, Fang Y, Chen F (2014) Endothelin-1 mediated high glucose-induced epithelial-mesenchymal transition in renal tubular cells. Diabetes Res Clin Pract 104: 176-182. https://doi.org/10.1016/j.diabres.2013.12.021

60. Tapmeier TT, Fearn A, Brown K, Chowdhury P, Sacks SH, Sheerin NS, Wong W (2010) Pivotal role of CD4+ T cells in renal fibrosis following ureteric obstruction. Kidney Int 78:351-362. https://doi. org/10.1038/ki.2010.177

61. Trachtman H, Nelson P, Adler S, Campbell KN, Chaudhuri A, Derebail VK, Gambaro G, Gesualdo L, Gipson DS, Hogan J, Lieberman K, Marder B, Meyers KE, Mustafa E, Radhakrishnan J, Srivastava T, Stepanians M, Tesar V, Zhdanova O, Komers R (2018) duet: a phase 2 study evaluating the efficacy and safety of sparsentan in patients with FSGS. DUET Study Group. J Am Soc Nephrol 29:2745-2754. https://doi.org/10.1681/ASN.2018010091

62. Tsuprykov O, Chaykovska L, Kretschmer A, Stasch JP, Pfab T, Krause-Relle K, Reichetzeder C, Kalk P, Adamski J, Hocher B (2015) Endothelin-1 overexpression improves renal function in eNOS knockout mice. Cell Physiol Biochem 37:1474-1490. https://doi.org/10.1159/000438516
63. Vanhove T, Goldschmeding R, Kuypers D (2017) Kidney fibrosis: origins and interventions. Transplantation 101:713-726. https://doi. org/10.1097/TP.0000000000001608

64. Venkatachalam MA, Weinberg JM, Kriz W, Bidani AK (2015) Failed tubule recovery, AKI-CKD transition, and kidney disease progression. J Am Soc Nephrol 26:1765-1776. https://doi.org/10. 1681/ASN.2015010006

65. Vignon-Zellweger N, Heiden S, Miyauchi T, Emoto N (2012) Endothelin and endothelin receptors in the renal and cardiovascular systems. Life Sci 91:490-500. https://doi.org/10.1016/j.lfs.2012. 03.026

66. Wang Y, Harris DC (2011) Macrophages in renal disease. J Am Soc Nephrol 22:21-27. https://doi.org/10.1681/ASN.2010030269

67. Wendel M, Knels L, Kummer W, Koch T (2006) Distribution of endothelin receptor subtypes ETA and ETB in the rat kidney. J Histochem Cytochem 54:1193-1203. https://doi.org/10.1369/jhc. 5A6888.2006

68. Zeisberg EM, Potenta SE, Sugimoto H, Zeisberg M, Kalluri R (2008) Fibroblasts in kidney fibrosis emerge via endothelial-tomesenchymal transition. J Am Soc Nephrol 19:2282-2287. https://doi.org/10.1681/ASN.2008050513

69. Zhang J, Yang W, Hu B, Wu W, Fallon MB (2014) Endothelin-1 activation of the endothelin $\mathrm{B}$ receptor modulates pulmonary endothelial CX3CL1 and contributes to pulmonary angiogenesis in experimental hepatopulmonary syndrome. Am J Pathol 184:17061714. https://doi.org/10.1016/j.ajpath.2014.02.027

Publisher's note Springer Nature remains neutral with regard to jurisdictional claims in published maps and institutional affiliations. 